\title{
Effects of seasonal and interannual events on satellite-derived phytoplankton biomass and production in the southernmost part of the California Current System during 2003-2016
}

\section{Efectos de eventos estacionales e interanuales en la biomasa y producción fitoplanctónicas derivadas de satélite en el extremo sur del Sistema de la Corriente de California en el periodo 2003-2016}

\author{
José Carlos Ortiz-Ahumada, Saúl Álvarez-Borrego ${ }^{+, *}$, Jose Gómez-Valdés \\ Centro de Investigación Científica y de Educación Superior de Ensenada, BC, División de Oceanología, \\ Carretera Ensenada-Tijuana \#3918, Zona Playitas, CP 22860, Ensenada, Baja California, México. \\ ${ }^{+}$ORCID ID 0000-0002-7586-8678. \\ * Corresponding author. E-mail: alvarezb@cicese.mx
}

\begin{abstract}
We characterized the spatial and temporal variations of sea surface temperature (SST), satellite-derived chlorophyll $a\left(\right.$ Chl $\left.{ }_{\text {sat }}\right)$ concentration, and phytoplankton production (PP) along two 300-km long transects in the southernmost part of the California Current System, one off Cabo San Lázaro (TCSLa) and the other off Cabo San Lucas (TCSLu). Moderate Resolution Imaging Spectroradiometer (Aqua-MODIS) SST and $\mathrm{Ch}_{\mathrm{sat}}$ monthly composites and PP monthly composites were used for the 2003-2016 period. An "average year" was generated for each transect and each variable, as an approximation to the climatology. The $\mathrm{Ch}_{\text {sat }}$ and $\mathrm{PP}$ values were higher in the inshore area than in the offshore area: $4.0 \mathrm{mg} \cdot \mathrm{m}^{-3}$ and $4.5 \mathrm{~g} \mathrm{C} \cdot \mathrm{m}^{-2} \cdot \mathrm{d}^{-1}$, respectively, for the inshore area of TCSLa and $1.4 \mathrm{mg} \cdot \mathrm{m}^{-3}$ and $1.8 \mathrm{~g} \mathrm{C} \cdot \mathrm{m}^{-2} \cdot \mathrm{d}^{-1}$, respectively, for the inshore area of TCSLu; $0.1 \mathrm{mg} \cdot \mathrm{m}^{-3}$ and $0.4 \mathrm{~g} \mathrm{C} \cdot \mathrm{m}^{-2} \cdot \mathrm{d}^{-1}$, respectively, for the offshore area of both transects. In general, SST showed minimum values $\left(\sim 17.0^{\circ} \mathrm{C}\right)$ in the inshore area and maximum values $\left(\sim 29.4^{\circ} \mathrm{C}\right)$ in the offshore area. $\mathrm{Chl}_{\text {sat }}$ values in the coastal zone were higher on TCSLa than on TCSLu, but offshore $\mathrm{Chl}_{\mathrm{sat}}$ values were often higher on TCSLu than on TCSLa. Seasonal and interannual variations were observed on both transects, but the seasonal variations were dominant. The effects of "the Blob" in 2014 and of the 2015-2016 eastern Pacific type of El Niño were similarly strong off both capes but caused no collapse in phytoplankton biomass, which decreased to only approximately half the values for the non-El Niño years. The 2003 and 2010 central Pacific type of El Niño events also had strong impacts. The 2005 central Pacific type of El Niño had a strong impact on the biology of TCSLu, like the impact of the 2014 and 2015-2016 events, but not on the biology of TCSLa. The coastal dynamics in the California Current System show spatial variations; thus, seasonal and interannual events have different effects at different geographic locations.
\end{abstract}

Key words: California Current System, satellite data, phytoplankton biomass, phytoplankton production, spatiotemporal variation.

RESUMEN. Se caracterizó la variación espaciotemporal de la temperatura superficial del mar (TSM), la concentración de clorofila $a$ derivada de satélite $\left(\mathrm{Ch}_{\text {sat }}\right)$ y la producción primaria (PP) en el extremo sur del Sistema de la Corriente de California, en 2 transectos de $300 \mathrm{~km}$ de largo, uno frente a cabo San Lázaro (TCSLa) y otro frente a cabo San Lucas (TCSLu). Se utilizaron composiciones mensuales de TSM y Chl $1_{\text {sat }}$ del sensor Moderate Resolution Imaging Spectroradiometer (Aqua-MODIS) y composiciones mensuales de PP, para el periodo $2003-2016$. Se generó un "año promedio" para cada transecto y cada variable como aproximación a la climatología. Los valores de Chl $\mathrm{sat}_{\mathrm{y}} \mathrm{PP}$ fueron mayores en la zona costera que en la zona oceánica: $4.0 \mathrm{mg} \cdot \mathrm{m}^{-3}$ y $4.5 \mathrm{~g} \mathrm{C} \cdot \mathrm{m}^{-2} \cdot \mathrm{d}^{-1}$, respectivamente, para la zona costera de TCSLa y $1.4 \mathrm{mg} \cdot \mathrm{m}^{-3}$ y $1.8 \mathrm{~g} \mathrm{C} \cdot \mathrm{m}^{-2} \cdot \mathrm{d}^{-1}$, respectivamente, para la zona costera de TCSLu; $\sim 0.1 \mathrm{mg} \cdot \mathrm{m}^{-3}$ y $0.4 \mathrm{~g} \mathrm{C} \cdot \mathrm{m}^{-2} \cdot \mathrm{d}^{-1}$, respectivamente, para la zona oceánica de ambos transectos. En general, la TSM presentó los valores mínimos en la zona costera $\left(\sim 17.0^{\circ} \mathrm{C}\right)$ y los máximos en la zona oceánica $\left(\sim 29.4^{\circ} \mathrm{C}\right)$. Los valores de $\mathrm{Chl}_{\text {sat }}$ en la zona costera fueron mayores en TCSLa que en TCSLu, pero la $\mathrm{Chl}_{\text {sat }}$ en la zona oceánica a menudo fue mayor en TCSLu que en TCSLa. Hubieron variaciones estacionales e interanuales en ambos transectos, pero las variaciones estacionales fueron dominantes. Los efectos de "El Blob" de 2014 y El Niño del tipo Pacífico oriental de 2015-2016 fueron similarmente fuertes frente a ambos cabos, pero no hubo un colapso de la biomasa fitoplanctónica, la cual sólo disminuyó a aproximadamente la mitad de los valores de años sin El Niño. Los eventos El Niño del tipo Pacífico central de 2003 y 2010 también tuvieron impactos fuertes. El Niño del tipo Pacífico central de 2005 tuvo un impacto fuerte en la biología de TCSLu, similar al impacto de los eventos de 2014 y 2015-2016, pero no en la biología de TCSLa. Las variaciones espaciales de la dinámica costera del Sistema de la Corriente de California causan que los eventos estacionales e interanuales tengan diferentes efectos en localidades geográficas diferentes.

Palabras clave: Sistema de la Corriente de California, datos satelitales, biomasa fitoplanctónica, producción fitoplanctónica, variación espaciotemporal. 


\section{INTRODUCTION}

The California Current System (CCS) is a very large transitional area that forms the eastern boundary of the North Pacific Gyre, with the confluence of Subarctic Water, Tropical Surface Water, and Subtropical Surface Water (Hickey 1998). It basically consists of a wide $(>500 \mathrm{~km})$ equatorward surface (up to $300 \mathrm{~m}$ depth) current and a poleward subsurface flow at the edge of the continental shelf (Lynn and Simpson 1987). Equatorial Water penetrates the system through the southern limit in the form of a subsurface countercurrent near the coast (200 m depth). Researchers thought this countercurrent occurred as a narrow poleward surface flow during part of autumn and winter (Lynn and Simpson 1987), but the surface and subsurface countercurrents are independent phenomena (Durazo 2015). The CCS is characterized by a large number of meanders, eddies, filaments, fronts, and mesoscale structures that span for tens to hundreds of kilometers offshore and last from days to months (Hickey 1998, Espinosa-Carreón et al. 2004, Barocio-León et al. 2007).

In the CCS, wind-induced upwelling events, which show seasonal variability, bring cold, nutrient-rich waters along the coast, from Washington to Baja California (Huyer 1983). This results in phytoplankton biomass (chlorophyll $a$ concentration, $\mathrm{Chl}$ ) and phytoplankton production (PP) gradients, with high values in the inshore area and a clear decrease towards the offshore area (Fargion et al. 1993, Arroyo-Loranca et al. 2015). The high Chl and PP values in the inshore area $(0-120 \mathrm{~km}$ from the coast) sustain high populations abundances of marine mammals and birds, and important fisheries. However, the CCS is influenced by El Niño/Southern Oscillation (ENSO) events that are associated with an increase of sea surface temperature (SST) and a decrease of Chl and PP (Putt and Prézelin 1985; Torres-Moye and Alvarez-Borrego 1987; Reid 1988; Lynn et al. 1998; Kahru and Mitchell 2000, 2002). By contrast, events with anomalously low SSTs (La Niña) may have the opposite effect, with relatively high $\mathrm{Chl}$ and PP.

An anomalous warming in the North Pacific (known by the nickname "The Blob") led to major disturbances in the California Current ecosystem (Gentemann et al. 2017). The Blob, which was a very large mass of relatively warm Pacific water off the western coast of North America, appeared for the first time in the Gulf of Alaska in autumn 2013 (Bond et al. 2015), and its influence on the southernmost part of the CCS lasted until the end of November 2015 (see SST anomaly charts in NOAA 2017a). This marine heat wave persisted throughout 2013-2015 because of the atmospheric teleconnections that spanned the entire North Pacific (Di Lorenzo and Mantua 2016). In the area off the Baja California Peninsula, SST in coastal waters off northern Baja California in October 2014 was $\sim 6^{\circ} \mathrm{C}$ above the maximum temperatures of other years in the period 2008-2014 (Coronado-Álvarez et al. 2017). Similar anomalously high

\section{INTRODUCCIÓN}

El Sistema de la Corriente de California (SCC) es un área transicional muy extensa que forma la frontera oriental del giro del Pacífico Norte, y donde confluyen el Agua Subártica, el Agua Tropical Superficial y el Agua Subtropical Superficial (Hickey 1998). Consiste en una corriente superficial (hasta $300 \mathrm{~m}$ de profundidad) muy ancha $(>500 \mathrm{~km})$ con dirección hacia el ecuador y un flujo subsuperficial con dirección hacia el polo a lo largo de la orilla de la plataforma continental (Lynn y Simpson 1987). El Agua Ecuatorial penetra el sistema a través del límite sur en la forma de una contracorriente subsuperficial cerca de la costa (200 m de profundidad). Se pensaba que esta contracorriente se manifestaba en la superficie como un flujo costero estrecho hacia el polo durante parte del otoño y el invierno (Lynn y Simpson 1987), pero se tiene evidencia de que la contracorriente subsuperficial y la contracorriente superficial son fenómenos independientes (Durazo 2015). El SCC se caracteriza por presentar una gran cantidad de meandros, remolinos, filamentos, frentes y estructuras de mesoescala que se extienden de decenas a cientos de kilómetros mar adentro y que duran de días a meses (Hickey 1998, Espinosa-Carreón et al. 2004, Barocio-León et al. 2007).

En el SCC, los eventos de surgencia, que son generados por el viento y tienen variabilidad estacional, incorporan aguas frías y ricas en nutrientes a lo largo de la costa, desde Washington hasta Baja California (Huyer 1983). Esto causa gradientes de biomasa fitoplanctónica (concentración de clorofila $a$, Chl) y producción fitoplanctónica (PP) con valores altos cerca de la costa y un decremento claro hacia mar adentro (Fargion et al. 1993, Arroyo-Loranca et al. 2015). Los valores altos de Chl y PP cerca de la costa $(0-120 \mathrm{~km}$ de la costa) mantienen poblaciones abundantes de mamíferos marinos y aves, y pesquerías importantes. Sin embargo, el SCC está influenciado por eventos El Niño/Oscilación del Sur (ENOS) que generan incrementos de temperatura superficial del mar (TSM) y decrementos de Chl y PP (Putt y Prézelin 1985; Torres-Moye y Alvarez-Borrego 1987; Reid 1988; Lynn et al. 1998; Kahru y Mitchell 2000, 2002). Por otro lado, los eventos con TSM anómalamente bajas (La Niña) pueden tener el efecto opuesto, valores relativamente altos de Chl y PP.

Un calentamiento anómalo del Pacífico Norte (conocido por el apodo "The Blob") produjo disturbios mayores en el ecosistema de la corriente de California (Gentemann et al. 2017). El Blob, que fue una masa de agua del Pacífico muy grande y relativamente caliente ubicada frente a la costa occidental de Norteamérica, apareció por primera vez en el golfo de Alaska en otoño de 2013 (Bond et al. 2015), y su influencia en la parte más sureña del SCC duró hasta el final de noviembre de 2015 (ver los mapas de anomalías de TSM en NOAA 2017a). Esta onda marina de calor persistió en 2013-2015 debido a las teleconexiones atmosféricas que abarcaron todo el Pacífico Norte (Di Lorenzo y Mantua 2016). En el área frente a la península de Baja California, la TSM de las 
Ortiz-Ahumada et al.: Effects of oceanographic events on phytoplankton in a current system

SST values were also recorded for the southernmost latitudes of the peninsula, off Cabo San Lucas (NOAA 2017a).

The coastal southernmost part of the CCS has been studied very little. The program Investigaciones Mexicanas de la Corriente de California only covers down to what was line 137 of the California Cooperative Oceanic Fisheries Investigations program, off the southern part of the Gulf of Ulloa (Durazo and Gaxiola-Castro 2010). The main objective of this work is to describe and quantify satellite-derived chlorophyll $a\left(\mathrm{Ch}_{\text {sat }}\right)$ and PP variabilities in 2 contrasting areas, Cabo San Lázaro and Cabo San Lucas (Fig. 1), at seasonal and interannual scales, and to explore the possible forcing agents underlying these variations. The main hypotheses are (1) there are clear inshore-offshore $\mathrm{Chl}_{\text {sat }}$ and PP gradients, with higher values in the inshore than in the offshore area at both studied sites; (2) inshore $\mathrm{Chl}_{\text {sat }}$ and PP values are greater off Cabo San Lázaro than off Cabo San Lucas; and (3) the impact of warm interannual events like El Niño is larger off Cabo San Lucas than off Cabo San Lázaro.

\section{MATERIALS AND METHOdS}

\section{Study areas}

The area off Cabo San Lázaro (CSLa) is the southern limit of the Biological Activity Center of the Gulf of Ulloa (Martínez-López and Verdugo-Díaz 2000). The oceanic zone off Magdalena Bay, immediately to the south of CSLa, is dynamically complex; it shows high seasonal and interannual variabilities, and its circulation patterns generate a sequence of eutrophic and oligotrophic conditions (Longhurst et al. 1967, Walsh et al. 1977). Eutrophic conditions occur in March-June and are directly associated with strong winds from the northwest, a well-developed

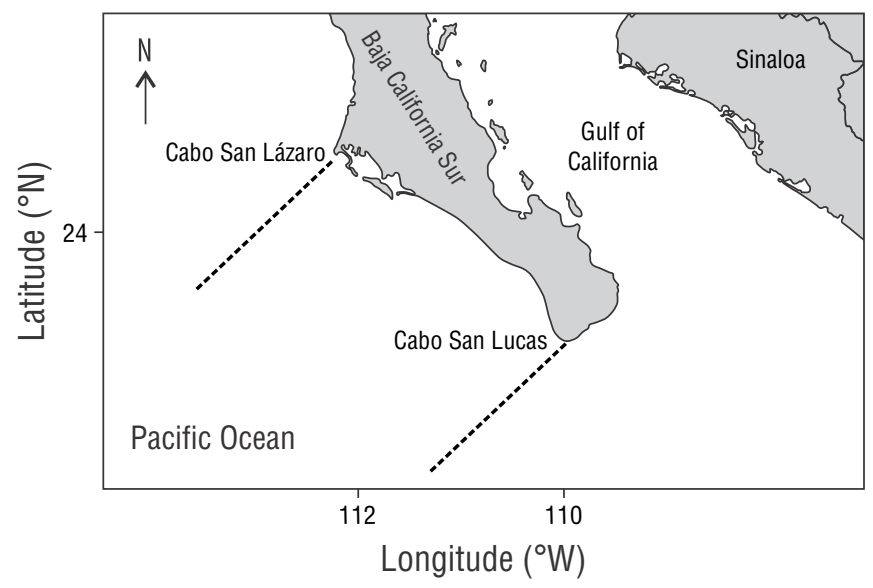

Figure 1. Transects (dashed lines) off Cabo San Lázaro and Cabo San Lucas.

Figura 1. Transectos (líneas discontinuas) frente a cabo San Lázaro y cabo San Lucas. aguas costeras frente al norte de Baja California en octubre de 2014 fue $\sim 6^{\circ} \mathrm{C}$ por encima de las temperaturas máximas de otros años en el periodo 2008-2014 (Coronado-Álvarez et al. 2017). Valores de TSM anómalamente altos también se registraron en las latitudes más sureñas de la península, frente a cabo San Lucas (NOAA 2017a).

La parte costera más sureña del SCC ha sido la menos estudiada. El programa Investigaciones Mexicanas de la Corriente de California cubre sólo hasta lo que fue la línea 137 del programa California Cooperative Oceanic Fisheries Investigations, frente a la parte sur del golfo de Ulloa (Durazo y Gaxiola-Castro 2010). El objetivo principal de este trabajo es describir y cuantificar las variaciones de la concentración de clorofila $a\left(\mathrm{Ch}_{\mathrm{sat}}\right)$ y PP, derivadas de satélite, frente a 2 áreas contrastantes, cabo San Lázaro y cabo San Lucas (Fig. 1), en las escalas estacional e interanual, y explorar los posibles agentes forzantes de estas variaciones. Las hipótesis principales son (1) hay gradientes claros de $\mathrm{Ch}_{\text {sat }}$ y PP de la costa a mar adentro, con valores más altos en la zona costera que en mar adentro en ambas áreas estudiadas; (2) los valores de $\mathrm{Ch}_{\text {sat }}$ y PP de la zona costera son mayores frente a cabo San Lázaro que frente a cabo San Lucas; y (3) el impacto de los eventos interanuales cálidos como El Niño son más grandes frente a cabo San Lucas que frente a cabo San Lázaro.

\section{MATERIALES Y MÉTODOS}

\section{Áreas de estudio}

El área frente a cabo San Lázaro (CSLa) es el límite sur del Centro de Actividad Biológica del golfo de Ulloa (Martínez-López y Verdugo-Díaz 2000). La zona oceánica frente a bahía Magdalena, inmediatamente al sur de CSLa es dinámicamente compleja; muestra alta variabilidad estacional e interanual, y sus patrones de circulación generan una alternancia entre condiciones eutróficas y oligotróficas (Longhurst et al. 1967, Walsh et al. 1977). Las condiciones eutróficas ocurren de marzo a junio y están directamente relacionadas con los vientos fuertes del noroeste, una corriente de California bien desarrollada y los valores máximos del índice de surgencias (Bakun y Nelson 1977). Las condiciones oligotróficas se presentan de septiembre a diciembre y están relacionadas con agua de alta salinidad, transportada por la contracorriente costera superficial, y con la relajación de las surgencias. Julio, agosto, enero y febrero son considerados como meses de transición (Bakun y Nelson 1977).

En la zona frente a cabo San Lucas (CSLu) se encuentra un frente oceánico. Dicho frente se manifiesta desde la superficie hasta $120 \mathrm{~m}$ de profundidad, y se debe al encuentro de diferentes masas de agua: Agua del Golfo de California, Agua de la Corriente de California y Agua del Pacífico Subtropical Nororiental (Griffiths 1963). Warsh et al. (1973) identificaron una cuarta masa de agua que también puede influir en la formación del frente, el Agua Subtropical Subsuperficial del Pacífico nororiental, localizada a 50-200 m de profundidad. 
California Current, and maximum upwelling index values (Bakun and Nelson 1977). Oligotrophic conditions occur in September-December and are associated with high-salinity water, which is transported by the surface coastal countercurrent, and with the relaxation of upwelling; July, August, January, and February are considered transition months (Bakun and Nelson 1977).

There is an oceanic front in the area off Cabo San Lucas (CSLu). The front extends from the surface down to $120 \mathrm{~m}$ depth, and it is formed by the confluence of different water masses: Gulf of California Water, California Current Water, and Northeast Pacific Subtropical Water (Griffiths 1963). Warsh et al. (1973) identified another water mass that can also contribute to the formation of the front, the northeastern Pacific Subtropical Subsurface Water, located at 50-200 m depth. The Cabo San Lucas Front is present during most of the year, though there are months when it weakens because of the decreasing effect of the California Current. Circulation at the front is affected by the warm gulf water, which moves westward near the coast, and the cold California Current water, which also moves westward but away from shore (Álvarez-Arellano and Molina-Cruz 1984).

$\mathrm{PP}$ and $\mathrm{Chl}_{\text {sat }}$ values have been reported for the area off CSLa: $0.31 \mathrm{~g} \mathrm{C} \cdot \mathrm{m}^{-2} \cdot \mathrm{d}^{-1}$ (from ${ }^{14} \mathrm{C}$ incubations, Longhurst et al. 1967) and up to $4.5 \mathrm{mg} \cdot \mathrm{m}^{-3}$ (data from the Coastal Zone Color Scanner, CZCS; Zuria-Jordán et al. 1995), respectively. These values are the result of upwelling events. When upwelling relaxes by the effect of the surface countercurrent, among other causes, $\mathrm{PP}$ and $\mathrm{Ch}_{\text {sat }}$ values decrease to less than $0.08 \mathrm{~g} \mathrm{C} \cdot \mathrm{m}^{-2} \cdot \mathrm{d}^{-1}$ (from ${ }^{14} \mathrm{C}$ incubations, Gaxiola-Castro and Álvarez-Borrego 1986) and $0.36 \mathrm{mg} \cdot \mathrm{m}^{-3}$ (Zuria-Jordán et al. 1995), respectively. On the other hand, Lara-Lara and Bazán-Guzmán (2005) reported Chl and PP values of $0.32 \mathrm{mg} \cdot \mathrm{m}^{-3}$ and $0.16 \mathrm{~g} \mathrm{C} \cdot \mathrm{m}^{-2} \cdot \mathrm{d}^{-1}$, respectively, for the area off $\mathrm{CSLu}$; here, Chl was measured in water samples and PP by the ${ }^{14} \mathrm{C}$ incubation technique during an oceanographic cruise carried out in January 1999.

\section{Satellite data}

Monthly composites of SST and $\mathrm{Ch}_{\text {sat }}$ from the Moderate Resolution Imaging Spectroradiometer aboard the Aqua satellite (EOS PM) (Aqua-MODIS), for the period from January 2003 to December 2016, were used. These composites (level 3, $9 \times 9 \mathrm{~km}^{2}$ pixel size) were obtained from the NASA Ocean Color website (NASA 2017). Data for SST are from day measurements with $11 \mu \mathrm{m}$ radiation. Imagery for PP (pixel size $18 \times 18 \mathrm{~km}^{2}$ ) was obtained from the Oregon State University Ocean Productivity website (http://www. science.oregonstate.edu/ocean.productivity/index.php). Images were downloaded in .hdr format (Hierarchical Data Format). PP is given as a defined standard product calculated using the Behrenfeld and Falkowsky (1997) vertically generalized productivity model (VGPM). The VGPM is a non-spectral model with homogeneous vertical distribution
El Frente de cabo San Lucas persiste durante la mayor parte del año, aunque en ciertos meses se debilita por la disminución del efecto de la corriente de California. La circulación del frente es afectada por el agua cálida proveniente del golfo, que se mueve hacia el oeste cerca de la costa, y por el agua fría de la corriente de California, que también se mueve hacia el oeste hacia fuera de la costa (Álvarez-Arellano y Molina-Cruz 1984).

Se han reportado valores de $\mathrm{PP}$ y de $\mathrm{Chl}_{\text {sat }}$ para el área frente a CSLa: $0.31 \mathrm{~g} \mathrm{C} \cdot \mathrm{m}^{-2} \cdot \mathrm{d}^{-1}$ (incubaciones con ${ }^{14} \mathrm{C}$, Longhurst et al. 1967) y hasta $4.5 \mathrm{mg} \cdot \mathrm{m}^{-3}$ (datos del sensor Coastal Zone Color Scanner, CZCS; Zuria-Jordán et al. 1995), respectivamente. Estos valores son causados por eventos de surgencia. Una vez que estos eventos se relajan por el efecto de la contracorriente superficial, además de otras causas, los valores de PP y $\mathrm{Chl}_{\text {sat }}$ disminuyen a valores por debajo de $0.08 \mathrm{~g} \mathrm{C} \cdot \mathrm{m}^{-2} \cdot \mathrm{d}^{-1}$ (incubaciones con ${ }^{14} \mathrm{C}$, Gaxiola-Castro y Álvarez-Borrego 1986) y $0.36 \mathrm{mg} \cdot \mathrm{m}^{-3}$ (Zuria-Jordán et al. 1995), respectivamente. Por otro lado, Lara-Lara y Bazán-Guzmán (2005) reportaron valores de $\mathrm{Chl}$ de $0.32 \mathrm{mg} \cdot \mathrm{m}^{-3}$ y valores de $\mathrm{PP}$ de $0.16 \mathrm{~g} \mathrm{C} \cdot \mathrm{m}^{-2} \cdot \mathrm{d}^{-1}$ para la zona frente a CSLu; en este último trabajo, Chl se midió en muestras de agua y PP por incubaciones con ${ }^{14} \mathrm{C}$ en un crucero oceanográfico realizado en enero de 1999.

\section{Datos de satélite}

Se utilizaron composiciones mensuales de TSM y de $\mathrm{Chl}_{\text {sat }}$ del sensor Moderate Resolution Imaging Spectroradiometer a bordo del satélite Aqua (EOS PM) (Aqua-MODIS), para el periodo de julio de 2002 a diciembre de 2016. Estas composiciones (nivel 3, tamaño de pixel de $9 \times 9 \mathrm{~km}^{2}$ ) se obtuvieron del sitio web Ocean Color de la Administración Nacional de la Aeronáutica y del Espacio (NASA, por sus siglas en inglés; NASA 2017). Los datos de TSM se midieron de día y con radiación de $11 \mu \mathrm{m}$. Las imágenes de PP (tamaño de pixel de $18 \times 18 \mathrm{~km}^{2}$ ) se obtuvieron del sitio web Ocean Productivity de Oregon State University (http://www.science.oregonstate. edu/ocean.productivity/index.php). Las imágenes se descargaron en formato .hdr (Hierarchical Data Format). La PP es proporcionada como un producto estándar ya calculado con el modelo de producción vertical generalizado (VGPM, por sus siglas en inglés) de Behrenfeld y Falkowsky (1997). El VGPM es un modelo no espectral con distribución vertical homogénea de biomasa y producción verticalmente integrada. Las imágenes satelitales se procesaron con programática de la NASA (SeaDAS v.7.1), también obtenida del sitio web Ocean Color (NASA 2017).

Para describir las variaciones espaciales y temporales de TSM, Chl $1_{\text {sat }}$ y PP se muestrearon 2 transectos de $300 \mathrm{~km}$ de longitud de las composiciones mensuales, uno frente a CSLa (TCSLa) y el otro frente a CSLu (TCSLu) (Fig. 1). Para describir estas variaciones temporales con más detalle, se generaron series de tiempo de sus promedios mensuales de 2 cuadrantes costeros $\left(18 \times 18 \mathrm{~km}^{2}\right)$, uno ubicado frente a 
Ortiz-Ahumada et al.: Effects of oceanographic events on phytoplankton in a current system

of biomass and with vertically integrated production. Satellite imagery was processed with the software provided by NASA (SeaDAS v.7.1), which was also obtained from the Ocean Color website (NASA 2017).

Two 300-km long transects, one off CSLa (TCSLa) and the other off CSLu (TCSLu) (Fig. 1), were sampled from the $\mathrm{SST}, \mathrm{Chl}_{\mathrm{sat}}$, and PP monthly composites to describe the spatial and temporal variations of these properties. In order to describe these temporal variations in detail, time series were generated for each property with their monthly averages for 2 coastal quadrants $\left(18 \times 18 \mathrm{~km}^{2}\right)$, one off CSLa and the other off CSLu. A time-series analysis of the 3 variables was performed to characterize the frequencies with the largest contributions to variability.

As a first approximation to the climatology, an "average year" was generated for each property and for each transect. To do this, all data for the Januaries were averaged, and then all data for the Februaries, and so on for each variable and for each transect. Data from at least 30 years are required to generate a real climatology. According to the $\mathrm{Chl}_{\text {sat }}$ climatology, transects were divided into an inshore area (from the coast to $\sim 110 \mathrm{~km})$ and an offshore area $(110-300 \mathrm{~km})$. Also, the year was divided into 2 seasons according to the $\mathrm{Chl}_{\text {sat }}$ climatology for the inshore area.

Mann-Whitney tests were run to compare $\mathrm{Chl}_{\text {sat }}$ values between the 2 seasons, separately for inshore $(0-110 \mathrm{~km})$ and offshore (110-300 km) waters, for each transect. Mann-Whitney tests were also run to compare inshore and offshore waters, for each transect and for each season; and to compare between transects, separately for inshore and offshore waters and for each season. Hovmöller diagrams were built with SST and $\mathrm{Chl}_{\text {sat }}$ data from all years.

\section{RESULTS}

In general, the "average year" showed clear spatial variations on both transects (Fig. 2). During the first half of the year SST had a monotonic distribution, with low values in the inshore area and high values in the offshore area. However, SST maxima and minima occurred from August through December on TCSLa and in June, July, and December on TCSLu. On TCSLu, SST varied monotonically from August through November but with an inverse gradient, with values decreasing from the inshore to the offshore area. In general, for both transects, the "average year" was divided into 2 seasons: from January to June, with relatively low SSTs $\left(<23^{\circ} \mathrm{C}\right)$, even in the offshore area; and from July to December, with relatively high SSTs $\left(>23{ }^{\circ} \mathrm{C}\right.$ and up to $\sim 29^{\circ} \mathrm{C}$ ), except for December at TCSLa when values were between 22.0 and 23.0 ${ }^{\circ} \mathrm{C}$ (Fig. 2).

In the "average year," SST was clearly greater on TCSLu than on TCSLa. Maximum SST on TCSLa was $27.0^{\circ} \mathrm{C}$ and minimum SST was $17.3{ }^{\circ} \mathrm{C}$, whereas on TCSLu maximum SST was $28.9^{\circ} \mathrm{C}$ and minimum SST was $20.9^{\circ} \mathrm{C}$. On both transects SST minima and maxima occurred in the inshore
CSLa y el otro frente a CSLu. Se realizó un análisis espectral de las series de tiempo de las 3 variables para caracterizar las frecuencias con mayor variación.

Como una primera aproximación a la climatología, se generó un "año promedio" para cada variable y para cada transecto. Para hacer esto, se promediaron todos los datos de los eneros, luego los de los febreros, y así sucesivamente para cada variable y para cada transecto. Para generar una climatología verdadera se requieren datos de por lo menos 30 años. De acuerdo con la climatología de $\mathrm{Chl}_{\text {sat }}$, los transectos se dividieron en una zona costera (de la costa hasta $\sim 110 \mathrm{~km}$ ), y una oceánica (de 110 a $300 \mathrm{~km}$ ). También, con base en la climatología de $\mathrm{Chl}_{\mathrm{sat}}$ de la zona costera, el año se dividió en 2 "estaciones."

Se hicieron pruebas no paramétricas Mann-Whitney para comparar la $\mathrm{Ch}_{\text {sat }}$ entre las 2 estaciones separadamente para la zona costera $(0-110 \mathrm{~km})$ y para la zona oceánica (110-300 km) de cada transecto. También se aplicaron las pruebas Mann-Whitney para comparar entre las 2 zonas de cada transecto, para cada estación; y para comparar entre transectos, separadamente para la zona costera y la zona oceánica y para cada estación. Se construyeron diagramas Hovmöller con los datos de TSM y $\mathrm{Ch}_{\text {sat }}$ de todos los años.

\section{Resultados}

En general, el "año promedio" presentó una variación espacial muy clara en los 2 transectos (Fig. 2). La TSM presentó una distribución monotónica en la primera mitad del año, con valores bajos en la zona costera y valores elevados en la zona oceánica. Sin embargo, en TCSLa se presentaron máximos y mínimos de agosto a diciembre, y en TCSLu se presentaron en junio, julio y diciembre. En TCSLu la TSM varió de manera monotónica de agosto a noviembre pero con un gradiente inverso, y los valores disminuyeron de la costa hacia mar adentro. En general, el "año promedio" de ambos transectos se dividió en 2 estaciones: de enero a junio, con TSM relativamente bajas $\left(<23^{\circ} \mathrm{C}\right)$, aún en la zona oceánica; y de julio a diciembre, con TSM relativamente altas $\left(>23{ }^{\circ} \mathrm{C}\right.$ y hasta $\sim 29^{\circ} \mathrm{C}$ ), a excepción de diciembre en TCSLa, cuando la TSM fue de entre 22.0 y $23.0^{\circ} \mathrm{C}$ (Fig. 2).

En el "año promedio", la TSM fue claramente mayor en TCSLu que en TCSLa. El máximo de TSM en TCSLa fue $27.0^{\circ} \mathrm{C}$ y el mínimo fue $17.3^{\circ} \mathrm{C}$, mientras que en TCSLu la máxima TSM fue $28.9^{\circ} \mathrm{C}$ y la mínima $20.9^{\circ} \mathrm{C}$. En ambos transectos los máximos y mínimos de TSM se presentaron en septiembre y abril en la zona costera. La diferencia de TSM entre la zona costera y la zona oceánica fue, en general, $>1.0^{\circ} \mathrm{C}$, con valores de hasta $\sim 3^{\circ} \mathrm{C}$, pero en verano fue tan pequeña como $\sim 0.6^{\circ} \mathrm{C}$. Para la zona oceánica, los máximos y mínimos fueron, respectivamente, 25.8 y $20.8^{\circ} \mathrm{C}$ para TCSLa y 27.5 y $22.8^{\circ} \mathrm{C}$ para TCSLu (Fig. 2).

De acuerdo con la distribución espacial de $\mathrm{Ch}_{\text {sat }}$ para el "año promedio", la zona costera se puede considerar desde la costa hasta $\sim 110 \mathrm{~km}$ (sobre todo de mayo a julio) (Fig. 2). 
TCSLa
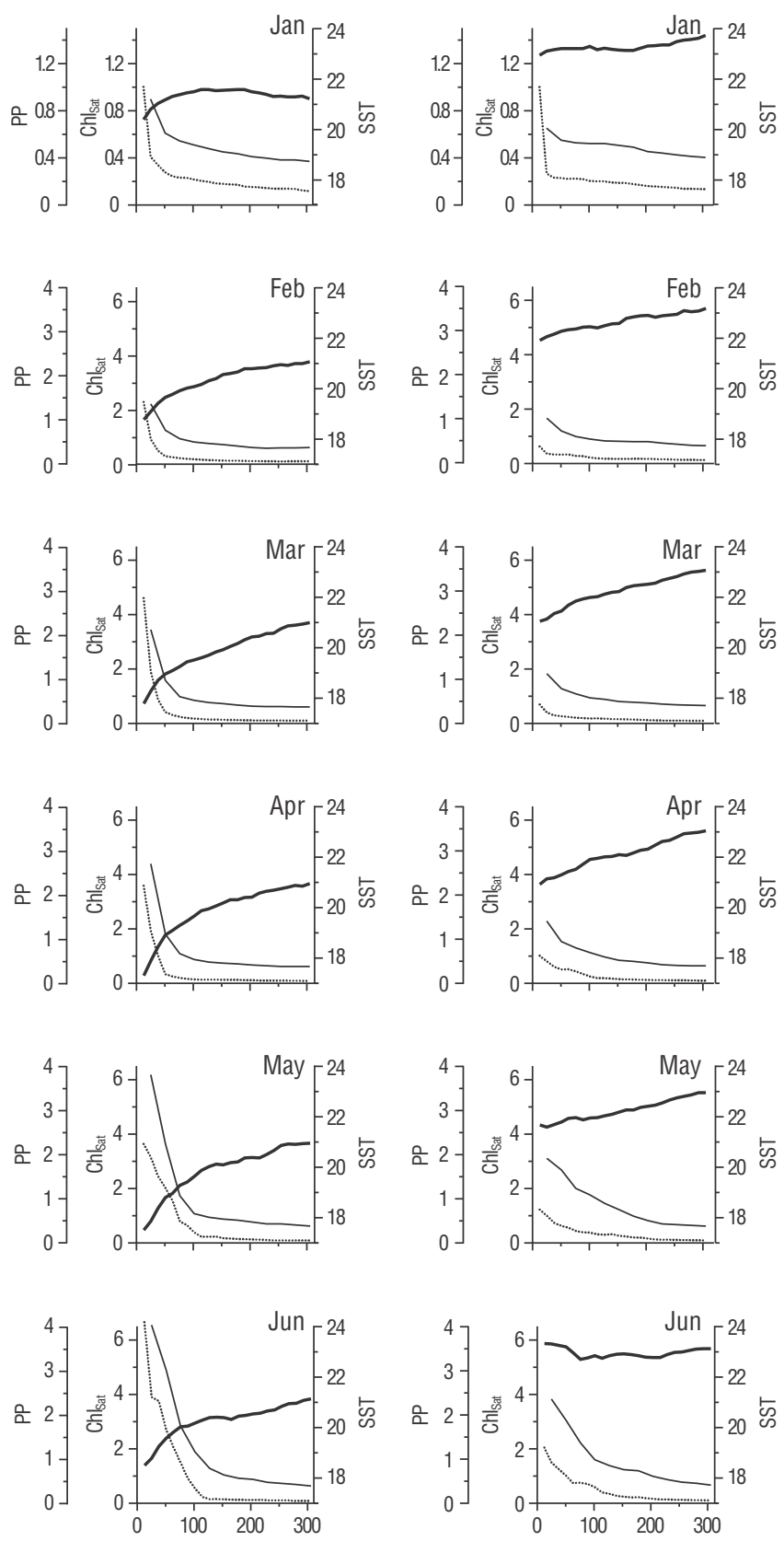

Distance (km)
TCSLa

TCSLu
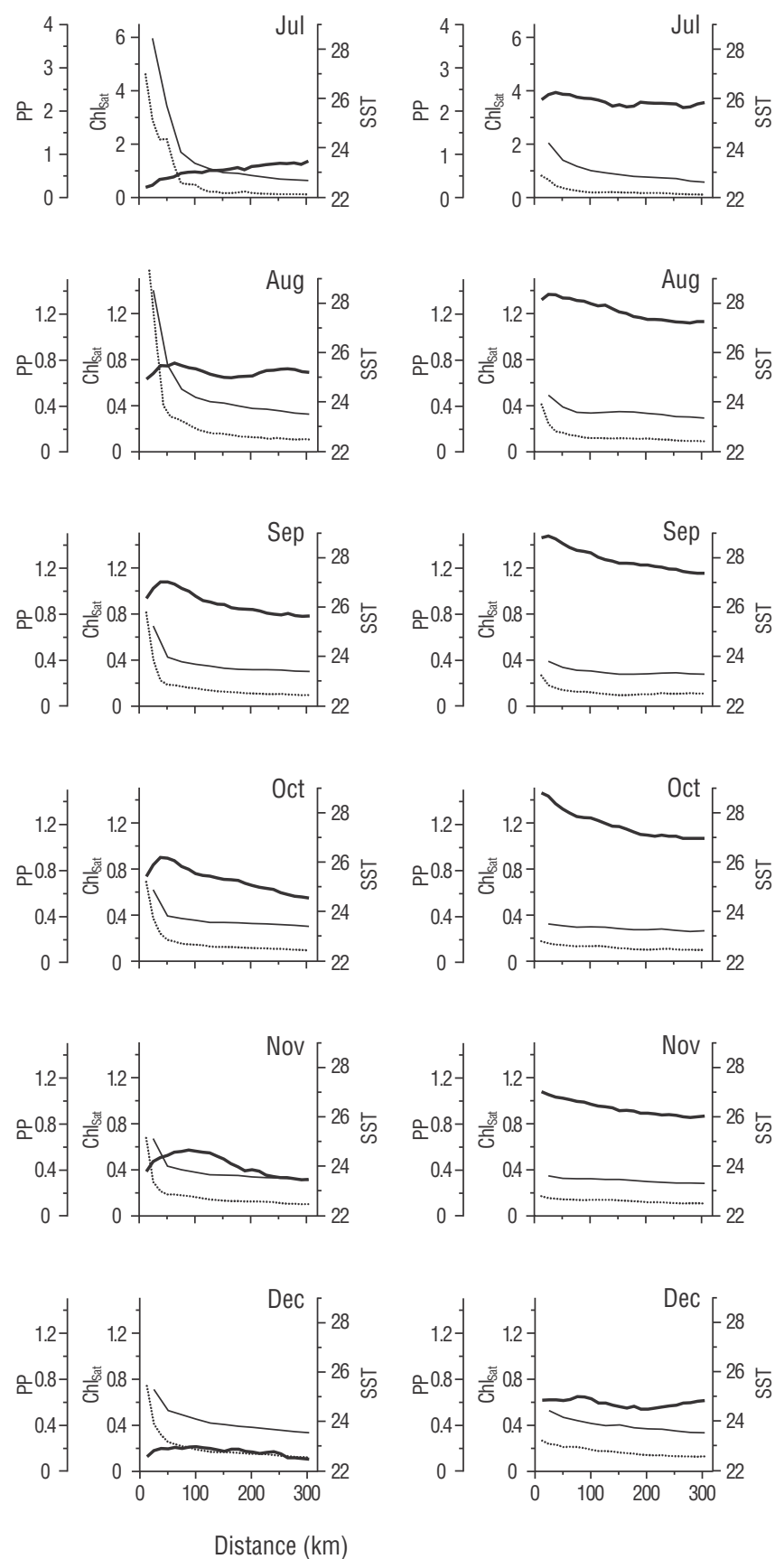

Distance $(\mathrm{km})$

$\mathrm{Chl}_{\mathrm{sat}}\left(\mathrm{mg} \cdot \mathrm{m}^{-3}\right)$

Figure 2. Climatology of 3 variables for the transect off Cabo San Lázaro (TCSLa) and the transect off Cabo San Lucas (TCSLu). The 3 variables are phytoplankton production (PP), satellite-derived chlorophyll $a\left(\mathrm{Chl}_{\mathrm{sat}}\right)$, and sea surface temperature (SST). Note that the scales for $\mathrm{Chl}_{\text {sat }}$ and PP for January and August-December are different from those for February-July; and the scale for SST for January-June is different from that for July-December.

Figura 2. Climatología de 3 variables para el transecto frente a Cabo San Lázaro (TCSLa) y el transecto frente a Cabo San Lucas (TCSLu). Las 3 variables son producción fitoplánctonica (PP), clorofila $a$ derivada de datos satelitale $\left(\mathrm{Chl}_{\text {sat }}\right.$ ) y temperatura superficial del mar (SST). Nótese que las escalas de $\mathrm{Chl}_{\text {sat }}$ y PP para enero y agosto-diciembre son diferentes de aquellas para febrero-julio y que la escala de SST para enero-junio es diferente de aquella para julio-diciembre. 
Ortiz-Ahumada et al.: Effects of oceanographic events on phytoplankton in a current system

area in April and September, respectively. The SST difference between the inshore and offshore areas was generally $>1.0^{\circ} \mathrm{C}$, with values up to $\sim 3.0^{\circ} \mathrm{C}$, but during the summer it was as small as $\sim 0.6^{\circ} \mathrm{C}$. For the offshore area, maxima and minima were, respectively, 25.8 and $20.8^{\circ} \mathrm{C}$ for TCSLa and 27.5 and $22.8^{\circ} \mathrm{C}$ for TCSLu (Fig. 2).

According to the $\mathrm{Chl}_{\mathrm{sat}}$ spatial distribution for the "average year," the inshore area can be considered to be from the coast to $\sim 110 \mathrm{~km}$ (mainly during May-July) (Fig. 2). In terms of $\mathrm{Chl}_{\mathrm{sat}}$ and PP climatology, the inshore biological conditions on TCSLa were grouped into 2 seasons: the first from February to August, with the highest value in June $\left(6.6 \mathrm{mg} \cdot \mathrm{m}^{-3}\right)$; and the second from September to January, with lower values than in the first season. The maximum value in the second season was $1.0 \mathrm{mg} \cdot \mathrm{m}^{-3}$ and it occurred in January, in the inshore area. Two seasons were also noted for the TCSLu inshore area: the first from February to July, with the highest value in June $\left(2.0 \mathrm{mg} \cdot \mathrm{m}^{-3}\right)$; and the second from August to January, with lower values $\left(<1.0 \mathrm{mg} \cdot \mathrm{m}^{-3}\right.$, except for a January value from the pixel closest to the coast) than in the first season. The lowest value in the "average year" for both transects was $\sim 0.1 \mathrm{mg} \cdot \mathrm{m}^{-3}$, and it occurred in the offshore area $(\sim 250$ to $300 \mathrm{~km}$ ).

The PP plots for the "average year" were very similar to the $\mathrm{Chl}_{\text {sat }}$ plots (Fig. 2). For both transects, there were 2 defined seasons for PP, as was the case for the $\mathrm{Chl}_{\mathrm{sat}}$ temporal variation. In the inshore area of both transects, the PP maxima for the first season occurred in June ( 4.0 and $2.3 \mathrm{~g}$ $\mathrm{C} \cdot \mathrm{m}^{-2} \cdot \mathrm{d}^{-1}$ for TCSLa and TCSLu, respectively), and the PP maxima for the second season occurred in January ( 0.9 and $0.7 \mathrm{~g} \mathrm{C}^{-\mathrm{m}^{-2}} \cdot \mathrm{d}^{-1}$ for TCSLa and TCSLu, respectively). PP minima for both transects were $0.4 \mathrm{~g} \mathrm{C} \cdot \mathrm{m}^{-2} \cdot \mathrm{d}^{-1}$ for the first season and $0.3 \mathrm{~g} \mathrm{C} \cdot \mathrm{m}^{-2} \cdot \mathrm{d}^{-1}$ for the second season (with the exception of the $0.4 \mathrm{~g} \mathrm{C} \cdot \mathrm{m}^{-2} \cdot \mathrm{d}^{-1}$ values in January), both occurring in the offshore area.

The year-to-year SST variation for both transects had clear seasonal and interannual components. During the studied period, SST on TCSLa ranged from $15.8^{\circ} \mathrm{C}$ (May 2006) to $29.1^{\circ} \mathrm{C}$ (August 2014) in the inshore area and from $19.0^{\circ} \mathrm{C}$ (April 2006) to $28.3^{\circ} \mathrm{C}$ (October 2015) in the offshore area. The SST range for the TCSLu inshore area was $19.3^{\circ} \mathrm{C}$ (April 2004 ) to $31.0^{\circ} \mathrm{C}$ (September 2015), and that for the TCSLu offshore area was $20.1{ }^{\circ} \mathrm{C}$ (February 2011) to $30.4{ }^{\circ} \mathrm{C}$ (August 2015).

There was an intense SST spatial gradient during the first season of every year, with colder waters in the inshore area than in the offshore area, whereas during the second season waters were relatively warm throughout both transects. Also, waters in the furthest offshore area were warmer during the second season than during the first. Thus, there were clear seasonal SST changes not only in the inshore area but also further offshore on both transects (Fig. 3).

In the inshore area of both transects SST values in the second season of 2005, 2007, and 2010 tended to be lower than SST values in the second season of other years. They
En términos de la climatología de $\mathrm{Chl}_{\text {sat }}$ y PP, las condiciones biológicas en TCSLa se agruparon en 2 estaciones: la primera de febrero a agosto, con el valor más alto en junio $\left(6.6 \mathrm{mg} \cdot \mathrm{m}^{-3}\right)$; y la segunda de septiembre a enero, con valores más bajos que los de la primera estación. En la segunda estación, el máximo fue $1.0 \mathrm{mg} \cdot \mathrm{m}^{-3}$ y se presentó en enero, en la zona costera. También se observaron 2 estaciones bien marcadas para la zona costera de TCSLu: la primera de febrero a julio, con el valor más alto en junio $\left(2.0 \mathrm{mg} \cdot \mathrm{m}^{-3}\right)$; y la segunda de agosto a enero, con valores más bajos $\left(<1.0 \mathrm{mg} \cdot \mathrm{m}^{-3}\right.$, a excepción del valor del pixel más cercano a la costa de enero) que en la primera estación. El valor más bajo del "año promedio" de ambos transectos fue $\sim 0.1 \mathrm{mg} \cdot \mathrm{m}^{-3}$, y se presentó en la zona más alejada de la costa ( 250 a $300 \mathrm{~km})$.

Las curvas de PP del "año promedio" fueron muy similares a las de $\mathrm{Chl}_{\text {sat }}$ (Fig. 2). En ambos transectos se observaron 2 estaciones bien definidas para PP, al igual que en el caso de la variación temporal de $\mathrm{Chl}_{\text {sat }}$. En la zona costera de ambos transectos, los máximos de PP para la primera estación se presentaron en junio $\left(4.0\right.$ y $2.3 \mathrm{~g} \mathrm{C} \cdot \mathrm{m}^{-2} \cdot \mathrm{d}^{-1}$ para TCSLa y TCSLu, respectivamente), y los máximos de PP para la segunda estación se presentaron en enero $\left(0.9 \mathrm{y} 0.7 \mathrm{~g} \mathrm{C} \cdot \mathrm{m}^{-2} \cdot \mathrm{d}^{-1}\right.$ para TCSLa y TCSLu, respectivamente). Los mínimos de PP para ambos transectos fueron $0.4 \mathrm{~g} \mathrm{C} \cdot \mathrm{m}^{-2} \cdot \mathrm{d}^{-1}$ en la primera estación y $0.3 \mathrm{~g} \mathrm{C} \cdot \mathrm{m}^{-2} \cdot \mathrm{d}^{-1}$ en la segunda (a excepción de enero que tuvo mínimos de $0.4 \mathrm{~g} \mathrm{C} \cdot \mathrm{m}^{-2} \cdot \mathrm{d}^{-1}$ ), y ambos mínimos se presentaron en la zona más alejada de la costa.

La variación de TSM de año a año, en ambos transectos, tuvo componentes estacionales e interanuales claros. Para el periodo de estudio, en la zona costera de TCSLa el rango de TSM fue de $15.8^{\circ} \mathrm{C}$ (mayo 2006) a $29.1^{\circ} \mathrm{C}$ (agosto 2014), y en la zona oceánica fue de $19.0^{\circ} \mathrm{C}$ (abril 2006) a $28.3^{\circ} \mathrm{C}$ (octubre 2015). En la zona costera de TCSLu el rango fue de $19.3{ }^{\circ} \mathrm{C}$ (abril 2006) a $31.0^{\circ} \mathrm{C}$ (septiembre 2015 ) y el de la zona oceánica fue de $20.1^{\circ} \mathrm{C}$ (febrero 2011) a $30.4^{\circ} \mathrm{C}$ (agosto 2015).

En la primera estación de cada año hubo un gradiente espacial intenso de TSM, con aguas más frías en la zona costera que en la zona oceánica, mientras que en la segunda estación las aguas fueron relativamente calientes en toda la extensión de los transectos. Además, las aguas de la región más oceánica fueron más calientes en la segunda estación que en la primera. Por lo tanto, hubieron cambios estacionales claros de TSM no sólo en la zona costera, sino también en la oceánica, en ambos transectos (Fig. 3).

En la zona costera de ambos transectos, los valores de TSM de la segunda estación de 2005, 2007 y 2010 fueron menores que los de TSM de la segunda temporada de otros años. Estos valores fueron seguidos por valores de TSM de la primera estación de 2006, 2008 y 2011, que fueron menores que los valores de TSM de la primera estación de otros años. Este fenómeno fue más evidente en TCSLa que en TCSLu. Estos valores más bajos de TSM se registraron para toda la extensión de los transectos, de la costa hasta las aguas más oceánicas, principalmente en 2011 (Fig. 3). 
were followed by SST values from the first season of 2006, 2008, and 2011, which were lower than SST values in the first season of other years. This phenomenon was more evident on TCSLa than on TCSLu. These low SST values were recorded along the full extension of the transects, from the coast to the furthest offshore waters, mainly in 2011 (Fig. 3).

On the other hand, for both transects, SST values in the first season of 2010, 2014, 2015, and 2016 tended to be higher than SST values in the first season of other years, yet this phenomenon was more evident on TCSLu than on TCSLa. In 2010 the high SST values in the first season were followed by some of the lowest second-season SST values, and this relative cooling continued into the first season of 2011 throughout both transects. The high SST values in the first season of 2014 and 2015, however, were followed by some of the highest second-season SST values. In 2016 the second-season SSTs went back to "normal" on both transects (Fig. 3).

The largest negative SST anomalies (not illustrated), with respect to our climatology, were down to $-4.7^{\circ} \mathrm{C}$ (September 2010) for the TCSLa inshore waters, with relatively large negative anomalies (smaller than $-2.4^{\circ} \mathrm{C}$ ) throughout the transect. The largest positive SST anomalies for TCSLa were up to $+4.0^{\circ} \mathrm{C}$ (May 2015), with relatively large positive anomalies (in most cases greater than $+3.0^{\circ} \mathrm{C}$ ) throughout the transect. For TCSLu the largest negative SST anomalies were $-3.9^{\circ} \mathrm{C}$ (July 2010), with relatively large negative anomalies (smaller than $-2.6^{\circ} \mathrm{C}$ in most cases) extending throughout the transect. The largest positive SST anomalies for TCSLu were up to $+3.1^{\circ} \mathrm{C}$ (July 2014 and July 2015) in the inshore waters, with anomalies decreasing offshore to less than $+2.0^{\circ} \mathrm{C}$ (not illustrated).

In the year-to-year variation, $\mathrm{Chl}_{\text {sat }}$ and $\mathrm{PP}$ values were relatively high in the coastal zone of both transects $\left(\geq 1.0 \mathrm{mg} \cdot \mathrm{m}^{-3}\right.$ and $\geq 1.0 \mathrm{~g} \mathrm{C} \cdot \mathrm{m}^{-2} \cdot \mathrm{d}^{-1}$, respectively) in late spring and early summer; these values extended from the coast to $110 \mathrm{~km}$, although very often to only $30-50 \mathrm{~km}$. In the coastal zone, $\mathrm{Ch}_{\text {sat }}$ and PP variations showed clear seasonal and interannual components (Figs. 4, 5). Sometimes the $\mathrm{Chl}_{\text {sat }}$ maximum was not adjacent to the coast but between 10 and $40 \mathrm{~km}$ from shore. In comparison with the other studied years, the spatial extent of relatively high $\mathrm{Chl}_{\text {sat }}$ values was larger in 2008, 2011, and 2012 (from the coast to $>100 \mathrm{~km}$ offshore) on TCSLa, and in 2011, 2012, and 2013 on TCSLu (Fig. 4).

In the offshore waters of both transects, yearly $\mathrm{Chl}_{\text {sat }}$ minima fluctuated between 0.01 and $0.10 \mathrm{mg} \cdot \mathrm{m}^{-3}$ and $\mathrm{PP}$ minima between 0.02 and $0.30 \mathrm{~g} \mathrm{C} \cdot \mathrm{m}^{-2} \cdot \mathrm{d}^{-1}$. Also in these waters, $\mathrm{Chl}_{\text {sat }}$ maxima fluctuated between 0.10 and $0.60 \mathrm{mg} \cdot \mathrm{m}^{-3}$, and $\mathrm{PP}$ maxima ranged between 0.40 and $0.70 \mathrm{~g} \mathrm{C} \cdot \mathrm{m}^{-2} \cdot \mathrm{d}^{-1}$. There was no trend for the occurrence of these extreme values at particular times of the year.

Hovmöller diagrams showed greater spatial and temporal variations for $\mathrm{Chl}_{\mathrm{sat}}$ than for SST in the inshore but not the offshore waters of both transects. The seasonal and interannual $\mathrm{Chl}_{\text {sat }}$ variations were very clear for the inshore area but not
Por otro lado, en ambos transectos, en la primera estación de 2010, 2014, 2015 y 2016 hubieron valores de TSM más elevados que en otros años, aunque este fenómeno fue más evidente en TCSLu que en TCSLa. En 2010, los valores altos de TSM en la primera estación fueron seguidos por algunos de los valores más bajos de TSM de la segunda estación, y este enfriamiento relativo continuó hasta la primera estación de 2011, en toda la extensión de ambos transectos. Los altos valores de TSM de la primera estación de 2014 y 2015 fueron seguidos por algunos de los valores de TSM más altos de la segunda estación. En 2016, las TSM de la segunda estación regresaron a valores "normales" en ambos transectos (Fig. 3).

Las anomalías negativas más grandes de TSM (no ilustradas), con respecto a nuestra climatología, fueron de hasta $-4.7^{\circ} \mathrm{C}$ (septiembre de 2010) para la zona costera de TCSLa, con anomalías negativas relativamente grandes (menores que $-2.4^{\circ} \mathrm{C}$ ) en todo el transecto. Las anomalías positivas más grandes de TSM en TCSLa fueron de hasta $+4.0^{\circ} \mathrm{C}$ (mayo de 2015), con anomalías positivas relativamente grandes (en la mayoría de los casos mayores que $+3.0^{\circ} \mathrm{C}$ ) en todo el transecto. Las anomalías negativas más grandes de TSM en TCSLu fueron de hasta $-3.9^{\circ} \mathrm{C}$ (julio de 2010), con anomalías negativas relativamente grandes (menores que $-2.6^{\circ} \mathrm{C}$ en la mayoría de los casos) en todo el transecto. Las anomalías positivas más grandes de TSM en TCSLu fueron de hasta $+3.1^{\circ} \mathrm{C}$ (julio de 2014 y de 2015) en las aguas costeras, y disminuyeron hacia mar adentro hasta a menos $\mathrm{de}+2.0^{\circ} \mathrm{C}$ (no ilustradas).

En la variación de año a año, los valores de $\mathrm{Chl}_{\text {sat }}$ y PP fueron relativamente altos en la zona costera de ambos transectos $\left(\geq 1.0 \mathrm{mg} \cdot \mathrm{m}^{-3} \mathrm{y} \geq 1.0 \mathrm{~g} \mathrm{C} \cdot \mathrm{m}^{-2} \cdot \mathrm{d}^{-1}\right.$, respectivamente) a finales de la primavera e inicio del verano; estos valores se extendieron de la costa a $110 \mathrm{~km}$, aunque muy a menudo solamente hasta $30-50 \mathrm{~km}$. En la zona costera, $\mathrm{Chl}_{\text {sat }}$ y PP presentaron variaciones con componentes estacionales e interanuales claros (Figs. 4, 5). Algunas veces, el máximo de $\mathrm{Ch}_{\text {sat }}$ no estuvo adyacente a la costa, sino entre 10 y $40 \mathrm{~km}$ de la costa. En comparación con los otros años estudiados, la extensión espacial de los valores relativamente altos de $\mathrm{Chl}_{\text {sat }}$ fue mayor en 2008, 2011 y 2012 (de la costa a $>100 \mathrm{~km}$ mar adentro) en TCSLa, y en 2011, 2012 y 2013 en TCSLu (Fig. 4).

En las aguas más alejadas de la costa de ambos transectos, los valores mínimos de $\mathrm{Chl}_{\text {sat }}$ de cada año fluctuaron entre 0.01 y $0.10 \mathrm{mg} \cdot \mathrm{m}^{-3}$ y los mínimos de PP fluctuaron entre 0.02 y $0.30 \mathrm{~g} \mathrm{C} \cdot \mathrm{m}^{-2} \cdot \mathrm{d}^{-1}$. En estas aguas, los máximos de $\mathrm{Chl}_{\text {sat }}$ fluctuaron entre $0.10 \mathrm{y} 0.60 \mathrm{mg} \cdot \mathrm{m}^{-3}$, y el rango de los máximos de PP fue de $0.40 \mathrm{a} 0.70 \mathrm{~g} \mathrm{C} \cdot \mathrm{m}^{-2} \cdot \mathrm{d}^{-1}$. No hubo una tendencia para la ocurrencia de estos valores extremos en periodos particulares del año.

Los diagramas Hovmöller mostraron mayor variación espacial y temporal para $\mathrm{Chl}_{\text {sat }}$ que para TSM en la zona costera de ambos transectos, pero no así para la zona oceánica. Las variaciones estacional e interanual de $\mathrm{Ch}_{\text {sat }}$ fueron muy claras en la zona costera, pero no en la zona oceánica (Fig. 4). Los valores de $\mathrm{Chl}_{\text {sat }}$ de la zona costera fueron mucho 


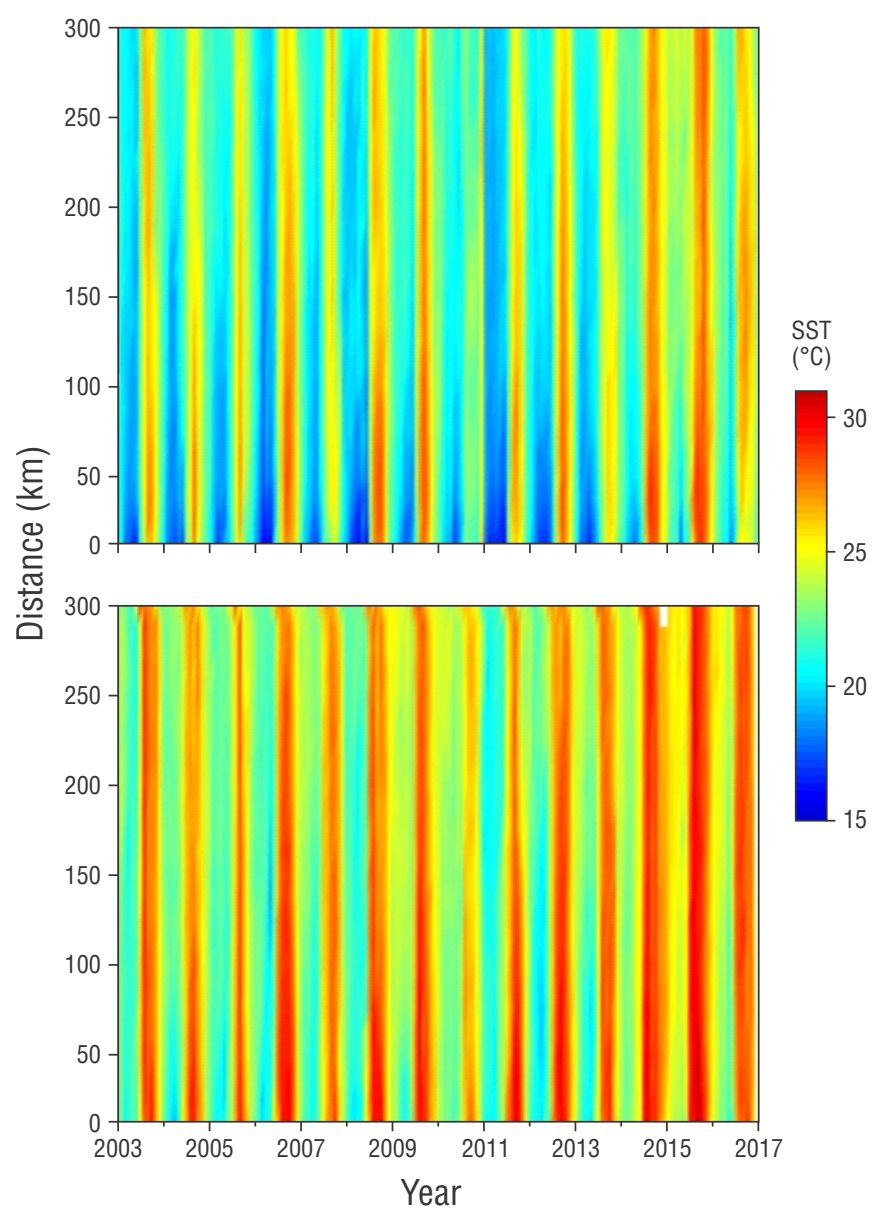

Figure 3. Hovmöller diagrams of sea surface temperature (SST) for the transect off Cabo San Lázaro (upper panel) and the transect off Cabo San Lucas (lower panel). Tick marks on the horizontal axes indicate the beginning of each year.

Figura 3. Diagramas Hovmöller de la temperatura superficial del mar (SST) para el transecto frente a cabo San Lázaro (panel superior) y para el transecto frente a cabo San Lucas (panel inferior). Las marcas en los ejes horizontales indican el inicio de cada año.

for the offshore area (Fig. 4). The $\mathrm{Chl}_{\text {sat }}$ inshore values from the first season were much higher, and showed longer duration, on TCSLa than on TCSLu.

With respect to other years in the study period, in the TCSLa inshore waters $\mathrm{Chl}_{\text {sat }}$ values from the first season were clearly lower (though some $>4 \mathrm{mg} \cdot \mathrm{m}^{-3}$ ) in $2010,2014,2015$, and 2016, and in the TCSLu inshore waters these values were lower (all $<2 \mathrm{mg} \cdot \mathrm{m}^{-3}$ ) in 2003, 2005, 2010, 2014, 2015, and 2016 (Fig. 4). In the TCSLa inshore waters, $\mathrm{Chl}_{\text {sat }}$ values from the first season were higher and showed larger spatial and temporal extension in 2006, 2008, 2011, and 2012 than in other years; in $2008 \mathrm{Chl}_{\mathrm{sat}}$ values $>4 \mathrm{mg} \cdot \mathrm{m}^{-3}$ were detected more than $100 \mathrm{~km}$ offshore (Fig. 4). In the TCSLu inshore waters, $\mathrm{Chl}_{\text {sat }}$ values from the first season were higher, albeit few $>4 \mathrm{mg} \cdot \mathrm{m}^{-3}$, and covered a larger spatial extension in 2011, 2012, and 2013 than in other years. On TCSLu relatively high $\mathrm{Chl}_{\text {sat }}$ values $\left(\sim 2 \mathrm{mg} \cdot \mathrm{m}^{-3}\right)$ were detected even at $\sim 200 \mathrm{~km}$ from

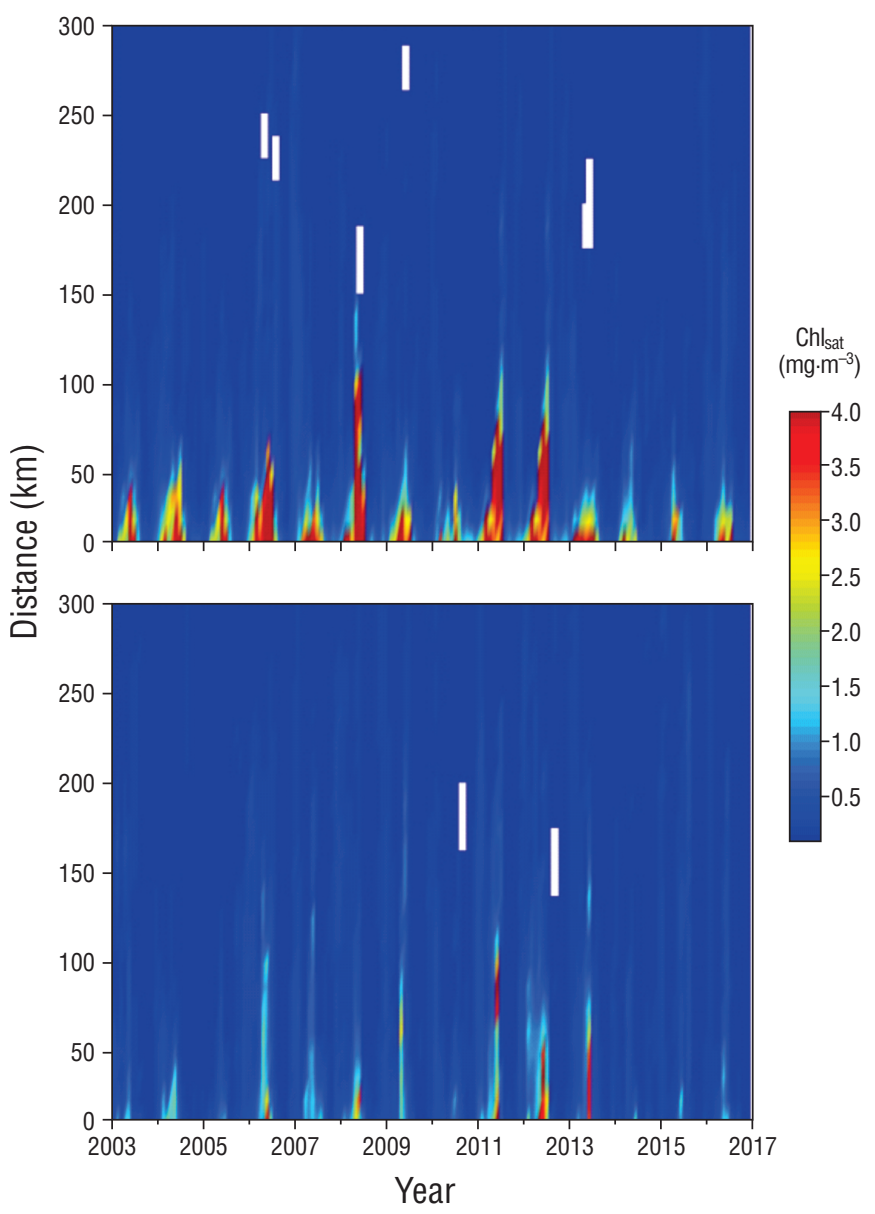

Figure 4. Hovmöller diagrams of satellite-derived chlorophyll $a$ $\left(\mathrm{Chl}_{\text {sat }}\right)$ for the transect off Cabo San Lázaro (upper panel) and the transect off Cabo San Lucas (lower panel). Tick marks on the horizontal axes indicate the beginning of each year.

Figura 4. Diagramas Hovmöller de clorofila $a$ derivada de satélite $\left(\mathrm{Chl}_{\mathrm{sat}}\right)$ para el transecto frente a cabo San Lázaro (panel superior) y para el transecto frente a cabo San Lucas (panel inferior). Las marcas en los ejes horizontales indican el inicio de cada año.

más elevados, y presentaron mayor duración, en TCSLa que en TCSLu.

En comparación con los otros años del periodo de estudio, en la zona costera de TCSLa los valores de $\mathrm{Chl}_{\text {sat }}$ de la primera estación fueron claramente más bajos (aunque algunos valores $>4 \mathrm{mg} \cdot \mathrm{m}^{-3}$ ) en 2010, 2014, 2015 y 2016, y en la de TCSLu estos valores fueron más bajos (todos los valores $<2 \mathrm{mg} \cdot \mathrm{m}^{-3}$ ) en 2003, 2005, 2010, 2014, 2015 y 2016 (Fig. 4). En las aguas costeras de TCSLa, los valores de $\mathrm{Ch}_{\mathrm{sat}}$ de la primera estación fueron claramente mayores y presentaron mayor extensión espacial y temporal en 2006, 2008, 2011 y 2012 que en los otros años estudiados; en 2008, los valores de $\mathrm{Chl}_{\text {sat }}>4 \mathrm{mg} \cdot \mathrm{m}^{-3}$ se presentaron hasta en $>100 \mathrm{~km}$ de la costa (Fig. 4). En las aguas costeras de TCSLu, los valores de $\mathrm{Chl}_{\text {sat }}$ de la primera estación fueron claramente mayores, aunque pocos $>4 \mathrm{mg} \cdot \mathrm{m}^{-3}$, y cubrieron una mayor extensión espacial en 2011, 2012 y 2013 que en los otros 

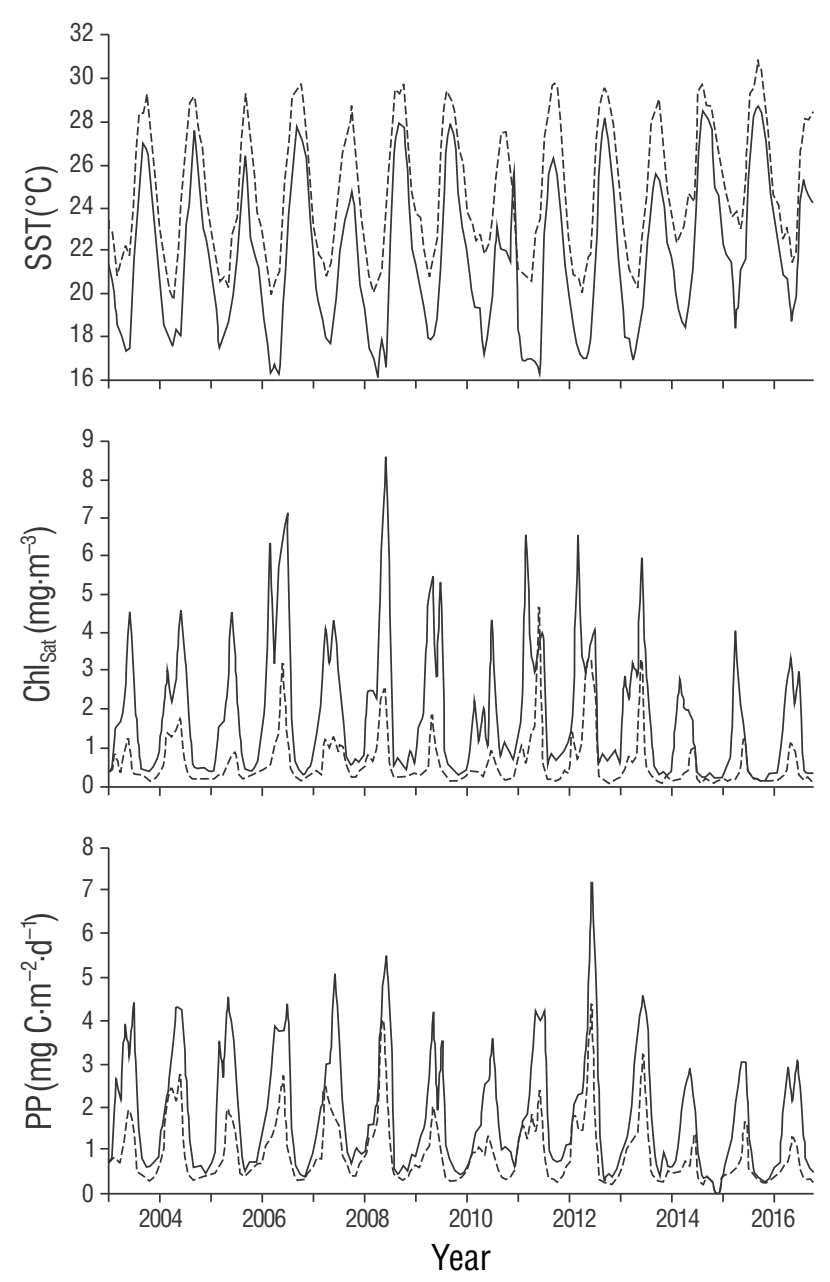

Figure 5. Time series of sea surface temperature (SST), satellitederived chlorophyll $a\left(\mathrm{Ch}_{\text {sat }}\right)$, and phytoplankton production (PP) in the $18 \times 18 \mathrm{~km}^{2}$ coastal quadrants off Cabo San Lázaro (continuous lines) and off Cabo San Lucas (dashed lines). Marks on the horizontal axes indicate the beginning of each year.

Figura 5. Series de tiempo de la temperatura superficial del mar (SST), clorofila $a$ derivada de satélite $\left(\mathrm{Chl}_{\text {sat }}\right)$ y producción fitoplanctónica en los cuadrantes costeros de $18 \times 18 \mathrm{~km}^{2}$ frente a cabo San Lázaro (líneas continuas) y frente a cabo San Lucas (líneas discontinuas). Las marcas en los ejes horizontales indican el inicio de cada año.

the coast for several years $(2006,2007,2009,2011,2012$, and 2013); in 2011, $\mathrm{Chl}_{\text {sat }}$ values $>4 \mathrm{mg} \cdot \mathrm{m}^{-3}$ were detected at 75-100 km from the coast (Fig. 4).

Results from the Mann-Whitney tests indicate that $\mathrm{Ch}_{\text {sat }}$ differences were significant in all comparisons, except for the comparison of the offshore $\mathrm{Chl}_{\text {sat }}$ values from the second season between transects (Table 1). These results indicate that $\mathrm{Chl}_{\text {sat }}$ values were significantly higher during the first season than during the second season in both zones and on both transects; that the $\mathrm{Chl}_{\text {sat }}$ values were significantly higher in inshore waters than in offshore waters during both seasons and on both transects; and that the inshore $\mathrm{Ch}_{\text {sat }}$ values were significantly higher on TCSLa than on TCSLu during both años estudiados. En TCSLu, durante varios años (2006, 2007, 2009, 2011, 2012 y 2013) hubieron valores de $\mathrm{Chl}_{\text {sat }}$ relativamente altos $\left(\sim 2 \mathrm{mg} \cdot \mathrm{m}^{-3}\right)$ hasta en $\sim 200 \mathrm{~km}$ fuera de la costa; en 2011 hubieron valores de $\mathrm{Chl}_{\text {sat }}$ de $>4 \mathrm{mg} \cdot \mathrm{m}^{-3}$ en $75-100 \mathrm{~km}$ de la costa (Fig. 4).

Los resultados de las pruebas Mann-Whitney indicaron que las diferencias de $\mathrm{Chl}_{\text {sat }}$ fueron significativas en todas las comparaciones, con excepción de la comparación de los valores de $\mathrm{Ch}_{\text {sat }}$ de la zona oceánica entre transectos para la segunda estación (Tabla 1). Estos resultados indican que los valores de $\mathrm{Chl}_{\text {sat }}$ fueron significativamente mayores en la primera estación que en la segunda, para las 2 zonas de los 2 transectos; que los valores de $\mathrm{Chl}_{\text {sat }}$ de la zona costera fueron significativamente mayores que los de la zona oceánica en ambas estaciones y en los 2 transectos; y que los valores de $\mathrm{Chl}_{\text {sat }}$ de la zona costera fueron significativamente mayores en TCSLa que en TCSLu durante las 2 estaciones, aunque los valores de $\mathrm{Chl}_{\mathrm{sat}}$ de la zona oceánica fueron mayores en TCSLa que en la de TCSLu en la primera estación, pero no en la segunda.

Las series de tiempo de TSM para los cuadrantes frente a ambos cabos mostraron que el ciclo anual dominó la variación de TSM (Fig. 5). El análisis espectral de las series de tiempo también mostró esto (no ilustrado). La TSM casi siempre fue menor en el cuadrante frente a CSLa que en el cuadrante frente a CSLu. Los máximos de TSM de ambas series de tiempo se presentaron al final del verano, y los mínimos en primavera. Los valores máximos de TSM de ambas series de tiempo, para nuestro periodo de estudio, se presentaron en septiembre de $2015\left(29.8^{\circ} \mathrm{C}\right.$ frente a CSLa y $31.0^{\circ} \mathrm{C}$ frente a CSLu). La diferencia estacional de TSM más grande para el cuadrante frente a CSLa fue $\sim 11.8^{\circ} \mathrm{C}$ y ocurrió en 2008; la del cuadrante frente a CSLu fue $9.7^{\circ} \mathrm{C}$ y ocurrió en 2012. La diferencia más grande entre máximos de años consecutivos fue $-3.5^{\circ} \mathrm{C}$ para CSLa y $-2.4{ }^{\circ} \mathrm{C}$ para CSLu, ambas entre 2015 y 2016 (Fig. 5).

Las series de tiempo de $\mathrm{Ch}_{\text {sat }}$ y PP para los cuadrantes costeros también mostraron la mayor variación en el ciclo anual (Fig. 5). Las series de tiempo de $\mathrm{Chl}_{\text {sat }}$ y PP presentaron más de un máximo en varios años. En el caso de $\mathrm{Chl}_{\text {sat }}$ hubieron 10 años con 2 máximos y 4 años con uno en el cuadrante frente a CSLa, y 6 años con 2 máximos y 8 años con uno en el cuadrante frente a CSLu. La PP no presentó el mismo número de años con 2 máximos que presentó $\mathrm{Ch}_{\text {sat; }}$; hubieron 4 años con 2 máximos de PP para CSLa y 5 años con 2 máximos de PP para CSLu (3 máximos para CSLa en 2003 y 3 máximos para CSLu en 2011). Se presentó un contraste muy claro entre los valores de $\mathrm{Chl}_{\text {sat }}$ y PP de ambos cuadrantes, ya que los valores fueron mayores frente a CSLa

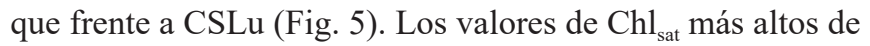
la primera estación se presentaron en 2008 frente a CSLa, y en 2011 frente a CSLu (8.6 y $4.7 \mathrm{mg} \cdot \mathrm{m}^{-3}$, respectivamente). Los valores más altos de PP se presentaron en ambos lugares en 2008, y fueron 5.5 y $4.8 \mathrm{~g} \mathrm{C} \cdot \mathrm{m}^{-2} \cdot \mathrm{d}^{-1}$ para CSLa y CSLu, respectivamente. 
Ortiz-Ahumada et al.: Effects of oceanographic events on phytoplankton in a current system

Table 1. Results of the Mann-Whitney tests comparing paired satellite-derived-chlorophyll- $a$ data sets: TCSLa, transect off Cabo San Lázaro; TCSLu, transect off Cabo San Lucas; CZ, coastal zone; OZ, offshore zone. Bold font indicates significantly different values.

Tabla 1. Resultados de las pruebas Mann-Whitney de la comparación de los conjuntos de datos pareados de la biomasa fitoplanctónica derivada de satélite: TCSLa, transecto frente a cabo San Lázaro; TCSLu, transecto frente a cabo San Lucas; CZ, zona costera; OZ, zona oceánica. La fuente en negritas indica valores significativamente diferentes.

\begin{tabular}{llll}
\hline TCSLa & CZ: First $v$ s second season & $n=1,296$ & $\boldsymbol{P}<\mathbf{0 . 0 0 1}$ \\
& OZ: First $v s$ second season & $n=2,154$ & $\boldsymbol{P}<\mathbf{0 . 0 0 1}$ \\
TCSLu & CZ: First $v s$ second season & $n=1,296$ & $\boldsymbol{P}<\mathbf{0 . 0 0 1}$ \\
& OZ: First $v s$ second season & $n=2,156$ & $\boldsymbol{P}<\mathbf{0 . 0 0 1}$ \\
TCSLa & First season: CZ $v s$ OZ & $n=1,723$ & $\boldsymbol{P}<\mathbf{0 . 0 0 1}$ \\
& Second season: CZ $v s$ OZ & $n=1,727$ & $\boldsymbol{P}<\mathbf{0 . 0 0 1}$ \\
TCSLu & First season: CZ $v s$ OZ & $n=1,728$ & $\boldsymbol{P}<\mathbf{0 . 0 0 1}$ \\
& Second season: CZ $v s$ OZ & $n=1,724$ & $\boldsymbol{P}<\mathbf{0 . 0 0 1}$ \\
CZ & First season: TCSLa $v s$ TCSLu & $n=1,296$ & $\boldsymbol{P}<\mathbf{0 . 0 0 1}$ \\
& Second season: TCSLa $v s$ TCSLu & $n=1,296$ & $\boldsymbol{P}<\mathbf{0 . 0 0 1}$ \\
OZ & First season: TCSLa $v$ TCSLu & $n=2,155$ & $\boldsymbol{P}<\mathbf{0 . 0 0 1}$ \\
& Second season: TCSLa $v s$ TCSLu & $n=2,155$ & $P=0.61$ \\
\hline
\end{tabular}

seasons, though the offshore $\mathrm{Chl}_{\text {sat }}$ values were higher on TCSLa than on TCSLu during the first season but not during the second season.

The SST time series showed that the annual cycle dominated the SST variation in the coastal quadrants off both capes (Fig. 5). Spectral analyses of the time series also showed this (not illustrated). Sea surface temperature was almost always higher off CSLu than off CSLa. In both time series SST maxima occurred at the end of summer and SST minima in spring. For both capes maximum SST values in our study period occurred in September 2015 , with $29.8^{\circ} \mathrm{C}$ off CSLa and $31.0^{\circ} \mathrm{C}$ off CSLu. The largest SST seasonal difference for the quadrant off CSLa was $\sim 11.8{ }^{\circ} \mathrm{C}$ and occurred in 2008; the one for the quadrant off CSLu was $9.7^{\circ} \mathrm{C}$ and occurred in 2012. The largest difference between maxima of consecutive years was $-3.5{ }^{\circ} \mathrm{C}$ for CSLa and $-2.4{ }^{\circ} \mathrm{C}$ for CSLu, both occurring between 2015 and 2016 (Fig. 5).

The $\mathrm{Chl}_{\mathrm{sat}}$ and PP time series also showed that the annual cycle dominated variations in both coastal quadrants (Fig. 5). The $\mathrm{Chl}_{\mathrm{sat}}$ and PP time series showed more than one maximum value for several years. In the case of $\mathrm{Chl}_{\text {sat }}$, there were 10 years with 2 maxima and 4 years with one for the quadrant off CSLa and 6 years with 2 maxima and 8 years with one for the quadrant off CSLu. PP did not show the same number of years with 2 maxima as $\mathrm{Ch}_{\text {sat }}$ did; there were 4 years with 2 PP maxima for CSLa and 5 years with 2 PP maxima for CSLu (3 maxima for CSLa in 2003 and 3 maxima for CSLu in 2011). There was a very clear contrast in $\mathrm{Chl}_{\text {sat }}$ and PP concentrations between the 2 quadrants, with higher values off CSLa than off CSLu (Fig. 5). The first-season $\mathrm{Chl}_{\text {sat }}$ values were highest in 2008 for CSLa and in 2011 for CSLu (8.6 and

\section{Discusión}

Los ciclos anuales de TSM, Chl $1_{\text {sat }}$ y PP en los transectos TCSLa y TCSLu (Figs. 2-5) están relacionados con la dinámica del SCC. Zuria-Jordán et al. (1995) reportaron valores de $\mathrm{Chl}_{\text {sat }}$, derivados del CZCS para la zona frente a CSLa, $\mathrm{y}$ encontraron que los valores fueron mayores de febrero a julio que durante el resto del año, similar a lo reportado en el presente estudio. El flujo de la corriente de California y las surgencias costeras se intensifican en primavera y principios de verano, promoviendo una señal biológica anual fuerte (Espinosa-Carreón et al. 2004).

Según Lynn y Simpson (1987) y Durazo et al. (2010), en invierno el flujo de la corriente de California y las surgencias costeras son débiles, y cerca de la costa hay una contracorriente superficial. Esta contracorriente superficial costera de invierno debería producir valores más altos de TSM y más bajos de $\mathrm{Chl}_{\text {sat }}$ y PP a finales de otoño y principios de invierno que en primavera y verano. Como lo mencionaron Arroyo-Loranca et al. (2015), el efecto de Coriolis causa que la contracorriente superficial acumule agua cerca de la costa inhibiendo las surgencias costeras. Por otro lado, la surgencia costera genera un flujo superficial hacia el sur (Mann y Lazier 2006), que inhibe un tanto la contracorriente superficial. En el periodo de surgencias costeras débiles (segunda estación) los valores de $\mathrm{Chl}_{\text {sat }}$ a menudo alcanzan valores $<0.2 \mathrm{mg} \cdot \mathrm{m}^{-3}$ (Figs. 2, 4), lo cual indica una situación oligotrófica en invierno con una variación estacional muy marcada.

Santamaría-del-Ángel et al. (1999) usaron datos del CZCS del golfo de California y concluyeron que, durante la estación sin surgencias, la $\mathrm{Ch}_{\text {sat }}$ se colapsa hasta $<0.1 \mathrm{mg} \cdot \mathrm{m}^{-3}$, lo cual ocurrió algunas pocas veces en la zona costera frente a CSLu. 
$4.7 \mathrm{mg} \cdot \mathrm{m}^{-3}$, respectively). The highest PP values occurred in 2008 for both sites, and they were 5.5 and $4.8 \mathrm{~g} \mathrm{C} \cdot \mathrm{m}^{-2} \cdot \mathrm{d}^{-1}$ for CSLa and CSLu, respectively.

\section{Discussion}

The SST, $\mathrm{Chl}_{\text {sat }}$ and PP annual cycles on the TCSLa and TCSLu transects (Figs. 2-5) are associated with the dynamics of the CCS. Zuria-Jordán et al. (1995) reported Chl sat values, derived from the CZCS for the area off CSLa, and found them to be higher from February to July than during the rest of the year, similar to what is reported in this study. The California Current and coastal upwelling events intensify in spring and at the beginning of summer, with a strong annual biological signal (Espinosa-Carreón et al. 2004).

According to Lynn and Simpson (1987) and Durazo et al. (2010), in winter the California Current and upwelling events are weak and a surface countercurrent flows near the coast. This winter surface countercurrent should produce higher SST values and lower $\mathrm{Chl}_{\text {sat }}$ and $\mathrm{PP}$ values in late autumn and early winter than in spring and summer. As indicated by Arroyo-Loranca et al. (2015), the surface countercurrent accumulates water near the coast because of the Coriolis effect, thus inhibiting coastal upwelling. On the other hand, coastal upwelling generates a southward surface flux (Mann and Lazier 2006), which inhibits the surface countercurrent to some extent. During the period of weak coastal upwelling (the second season) $\mathrm{Chl}_{\text {sat }}$ values are often $<0.2 \mathrm{mg} \cdot \mathrm{m}^{-3}$ (Figs. 2, 4), indicating oligotrophic conditions in winter and strong seasonal variations.

Santamaría-del-Ángel et al. (1999) used CZCS data from the Gulf of California and concluded that during the nonupwelling season, $\mathrm{Chl}_{\text {sat }}$ collapses to $<0.1 \mathrm{mg} \cdot \mathrm{m}^{-3}$, as was also sometimes the case for the coastal zone off CSLu. On the other hand, Arroyo-Loranca et al. (2015) and Mirabal-Gómez et al. (2017) reported that, respectively, for transects off Punta Eugenia and transects off northern Baja California and La Jolla, California, the lowest $\mathrm{Ch}_{\text {sat }}$ values during the nonupwelling season were $>0.1 \mathrm{mg} \cdot \mathrm{m}^{-3}$. Comparing these cases with the coastal area off CSLu, the southernmost part of the CCS does not maintain high PP throughout the year as most other parts of its extension do.

In the TCSLa coastal area, the $\mathrm{Ch}_{\text {sat }}$ values were 3 times the values found on TCSLu, indicating larger influence of upwelling events off CSLa than off CSLu during the first season. During the second season, the tendency to oligotrophic conditions caused by the surface countercurrent is stronger off CSLu than off CSLa. However, in the offshore zone, $\mathrm{Ch}_{\text {sat }}$ was sometimes much higher ( $\sim 10$ times) on TCSLu than on TCSLa because the circulation separating the California Current from the peninsula produces plumes that carry relatively high $\mathrm{Ch}_{\text {sat }}$ values offshore (up to $\sim 300 \mathrm{~km}$ ) in the area near CSLu (Fig. 6). The corresponding SST imagery for this area does not show these plumes with as much clarity as the $\mathrm{Chl}_{\text {sat }}$ imagery does. When there is not
En contraste, Arroyo-Loranca et al. (2015) y Mirabal-Gómez et al. (2017) reportaron que, respectivamente, para transectos frente a punta Eugenia y transectos frente al norte de Baja California y La Jolla, California, los valores más bajos de $\mathrm{Chl}_{\text {sat }}$ fueron $>0.1 \mathrm{mg} \cdot \mathrm{m}^{-3}$ en la estación sin surgencias. Al comparar estos casos con el de la zona costera frente a CSLu, la parte más sureña del SCC no mantiene a lo largo del año la PP alta que caracteriza a la mayor parte de la extensión del sistema.

El que $\mathrm{Chl}_{\text {sat }}$ sea hasta 3 veces mayor en la zona costera de TCSLa que en la de TCSLu indica una influencia mayor de los eventos de surgencia frente a CSLa que frente a CSLu en la primera estación. En la segunda estación, la tendencia hacia condiciones oligotróficas causada por el efecto de la contracorriente superficial costera es más fuerte frente a CSLu que frente a CSLa. Sin embargo, en la zona oceánica algunas veces $\mathrm{Chl}_{\text {sat }}$ fue mucho mayor ( $\sim 10$ veces) en TCSLu que en TCSLa; esto se debe a que la circulación que separa la corriente de California de la península produce lengüetas con valores de $\mathrm{Chl}_{\text {sat }}$ relativamente altos de la costa hacia mar adentro (hasta $\sim 300 \mathrm{~km}$ ) en la zona cercana a CSLu (Fig. 6). Las imágenes de TSM correspondientes a esta zona no muestran estos chorros con la claridad con la que lo hacen las imágenes de $\mathrm{Chl}_{\text {sat }}$ Ya se ha demostrado que cuando no hay contraste apropiado en las imágenes satelitales de TSM, las de $\mathrm{Ch}_{\text {sat }}$ pueden ser de gran ayuda para estudiar la dinámica superficial del mar (i.e., Pegau et al. 2002).

Las imágenes de satélite muestran la estructura rica de la distribución de pigmentos fotosintéticos desde la costa hasta cientos de kilómetros mar adentro, como fue reportado por Traganza (1985) y otros posteriormente. La distribución en forma de manchas se debe a una combinación de factores físicos, químicos y biológicos que afectan al fitoplancton, como la secuencia de la intensificación y el relajamiento de surgencias (como lo describieron Álvarez-Borrego y Álvarez-Borrego 1982), los movimientos de las masas de agua, los fenómenos de mesoescala y submesoescala, la mezcla por vientos (inclusas las tormentas) o por fenómenos asociados a las mareas, la distribución de nutrientes en forma de manchas, la reproducción diferencial del fitoplancton y el pastoreo diferencial (Yentsch 1981). Este tipo de fenómenos posiblemente fueron la causa de los múltiples máximos de $\mathrm{Chl}_{\text {sat }}$ y PP observados en las series de tiempo para las localidades costeras de ambos cabos (Fig. 5). El número menor de años con múltiples máximos de PP, comparados con los de $\mathrm{Chl}_{\text {sat }}$, se debe al proceso de integración con la profundidad para el cálculo de PP, el cual suaviza su variación.

Las variaciones interanuales de TSM, Chl $\mathrm{sat}_{\mathrm{y}}$ PP en la zona costera de nuestra área de estudio pudieron haber sido causadas principalmente por la secuencia de eventos ENOS y el Blob. La fase ENOS más fría (La Niña) de nuestro periodo de estudio se registró en 2011 en ambos transectos, con los valores más bajos de TSM y, en general, los más altos de $\mathrm{Chl}_{\text {sat }}$, pero los eventos La Niña de 2006, 2008 y 2012 también fueron fases negativas fuertes del ENOS (Figs. 3, 4). Hay 
enough contrast in SST imagery, $\mathrm{Chl}_{\text {sat }}$ imagery may be of great help to study the surface dynamics of the ocean (i.e., Pegau et al. 2002).

Satellite imagery shows the spatial distribution of photosynthetic pigments with a rich structure from the coast to hundreds of kilometers offshore, as was reported by Traganza (1985) and many others thereafter. A patchy distribution is caused by a combination of physical, chemical, and biological factors affecting phytoplankton, such as the sequence of upwelling intensification and relaxation (as described by Álvarez-Borrego and Álvarez-Borrego 1982), movements of water masses, mesoscale and sub-mesoscale phenomena, mixing by wind (including storms) or phenomena associated with tides, patchy distribution of nutrients, differential phytoplankton reproduction, and differential grazing (Yentsch 1981). These phenomena were likely the cause for the multiple $\mathrm{Chl}_{\text {sat }}$ and PP maxima observed in the time series for the coastal quadrants off both capes (Fig. 5). The number of years with multiple PP maxima was lower, compared with that for $\mathrm{Chl}_{\text {sat }}$, because the integration with depth in the calculation of PP tends to decrease its variation.

The SST, $\mathrm{Chl}_{\text {sat }}$, and PP interannual variations in the inshore zone of our study area could have been caused mainly by the sequence of ENSO events and the Blob. The coldest ENSO phase (La Niña) in our study period occurred in 2011 on both transects, with the lowest SSTs and, in general, the highest $\mathrm{Chl}_{\text {sat }}$ values, but the 2006, 2008, and 2012 La Niña events were also strong negative ENSO phases (Figs. 3, 4). There are 2 types of El Niño events: the eastern Pacific type (EP), with maximum SST anomalies centered in the region of the eastern equatorial Pacific cold plume; and the central Pacific type (CP), with SST anomalies near the time line (Kao and $\mathrm{Yu}$ 2009). The CP type of El Niño has also been referred to as El Niño Modoki (in Japanese meaning similar but different) (Ashok et al. 2007). Propagation of SST anomalies from the Equator to the northeastern Pacific is weaker and less clear in the CP type than in the EP type of El Niño. The EP type of El Niño is characterized by subsurface temperature anomalies that propagate through the Pacific basin; and the CP type of El Niño is more often associated with subsurface temperature anomalies that develop in situ in the central Pacific (Ashok et al. 2007).

The 1982-1983 and the 1997-1998 El Niño events were of the EP type, and it was not until 2015-2016 that another EP type of El Niño occurred, the latter of which impact on the biology of our study area lasted from June 2015 to the end of spring 2016 (Figs. 4, 5). However, El Niño and the Blob were overlapping events and it is not clear if both or only the Blob caused the decrease in $\mathrm{Chl}_{\text {sat }}$ and PP in the inshore waters of TCSLa and TCSLu throughout most of 2015. After September 2015 El Niño was the main cause for the low phytoplankton biomass observed in our study area. According to Robinson (2016) the recent warming off Baja California occurred in 2 distinct periods. In the first warming period, from May 2014 to April 2015, the SST increase was

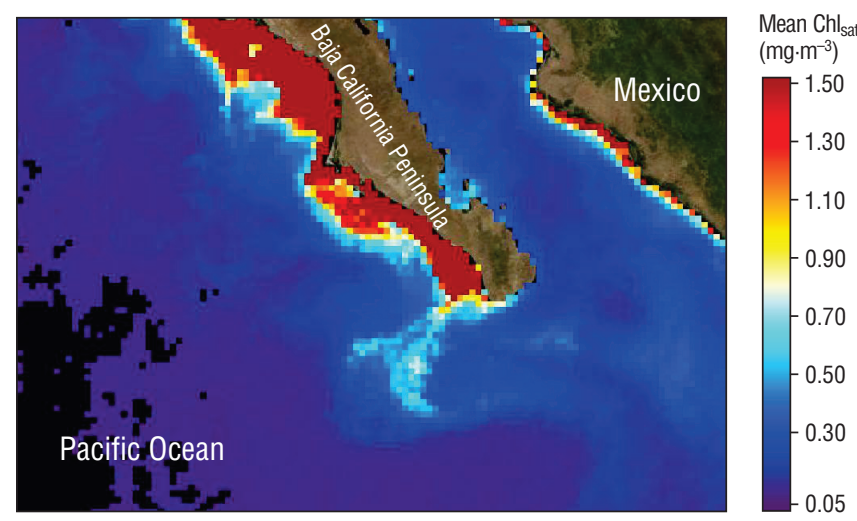

Figure 6. Image showing the California Current flowing away from the Baja California Peninsula and carrying relatively high satellite-derived chlorophyll $a$ concentrations $\left(\mathrm{Chl}_{\text {sat }}\right)$ towards oceanic waters (June 2009).

Figura 6. Imagen donde se muestra a la corriente de California separándose de la península de Baja California y acarreando concentraciones relativamente altas de clorofila $a$ derivada de satélite $\left(\mathrm{Chl}_{\mathrm{sat}}\right)$ hacia aguas oceánicas (junio de 2009).

2 tipos de eventos El Niño: el tipo Pacífico oriental (PO) que tiene un máximo de anomalías de TSM centrado en la región de la lengüeta fría del Pacífico ecuatorial oriental; y el tipo Pacífico central (PC) que tiene anomalías cerca de la línea del tiempo (Kao y Yu 2009). El Niño del tipo PC también ha sido denominado El Niño Modoki (del japonés: similar pero diferente) (Ashok et al. 2007). La propagación de las anomalías de TSM del Ecuador al Pacífico nororiental es más débil y menos clara en el ENOS del tipo PC que en el del tipo PO. El ENOS del tipo PO está caracterizado por anomalías de temperatura subsuperficiales que se propagan a través de la cuenca del Pacífico; y el ENOS del tipo PC está más relacionado con anomalías subsuperficiales de temperatura que se desarrollan in situ en el Pacífico central (Ashok et al. 2007).

Los eventos El Niño de 1982-1983 y 1997-1998 fueron del tipo PO, y no fue hasta 2015-2016 que ocurrió otro El Niño del tipo PO, que impactó en la biología de nuestra área de estudio desde junio de 2015 hasta el final de la primavera de 2016 (Figs. 4, 5). Sin embargo, hubo un traslape de El Niño y el Blob, y no es claro si ambos o sólo el Blob fue la causa de la disminución de $\mathrm{Chl}_{\text {sat }}$ y PP en las aguas costeras de TCSLa y TCSLu durante casi todo 2015. Después de septiembre de 2015, el efecto de El Niño fue la causa principal de los bajos valores de biomasa fitoplanctónica de nuestra área de estudio. De acuerdo con Robinson (2016), el calentamiento reciente frente a Baja California ocurrió durante 2 periodos distintos. En el primer periodo, de mayo de 2014 a abril de 2015, el aumento de TSM se relacionó con vientos costeros débiles no relacionados con El Niño (Robinson 2016). En este periodo se presentó el record más largo de anomalías negativas de viento. La reducción del estrés del viento sugiere un debilitamiento de las surgencias costeras. El segundo periodo de calentamiento ocurrió de septiembre a diciembre de 2015, 
related to weak coastal winds not associated with El Niño (Robinson 2016). The longest sustained record of negative wind anomalies occurred during this period. Reduced wind stress suggests weakened coastal upwelling. The second warming period occurred from September to December 2015, during strong El Niño conditions (Robinson 2016) (also during 2016 on TCSLu).

Torres-Moye and Alvarez-Borrego (1987) attributed the low phytoplankton biomass they found in coastal waters off northern Baja California in the summer of 1984 to the effect of the 1982-1983 El Niño event. During this event temperatures off Baja California remained high until spring 1984, and macroalgae populations started to recover in autumn 1984 (Hernández-Carmona 1988). The 1997-1998 event did not have the lasting impact the 1982-1984 event had (Ladah et al. 1999). The 1982-1984 event coincided with a warm regime in the North Pacific, while the 1997-1998 event coincided with a cold regime (Newman et al. 2003).

The impact of different ENSO events on phytoplankton and the populations of other organisms is not the same, and it depends, among other things, on the phase of the North Pacific Decadal Oscillation. Kahru and Mitchell (2002) reported that the effects of the 1997-1998 EP type of El Niño were observed as decreased PP starting in mid-1997 and disappearing in 1998 off central and southern California, whereas off southern Baja California, down to the area off CSLa, the effects of this El Niño event became evident later in mid-1998. Using principal component analyses, Herrera-Cervantes et al. (2013) described the interannual SST and $\mathrm{Chl}_{\text {sat }}$ variability patterns off Punta Eugenia $\left(26-29^{\circ} \mathrm{N}, 113-116^{\circ} \mathrm{W}\right)$ and suggested that ENSO cycles dominated the SST and $\mathrm{Chl}_{\text {sat }}$ interannual variations in coastal waters but that variations in deep waters were driven by the intrusion of subarctic water rather than by ENSO cycles.

In the present study, with respect to values from years like 2008, 2011, and 2012, $\mathrm{Chl}_{\text {sat }}$ and PP decreased by $>50 \%$ in the TCSLa and TCSLu inshore waters during the Blob in 2014 and during the 2015-2016 EP El Niño. Zaba and Rudnick (2016) reported that, off southern California, the thermocline was depressed and strong stratification lasted from the summer of 2014 through to the 2015-2016 winter. Something similar may have happened in the southernmost part of the CCS, and this would explain the relatively low phytoplankton biomass on TCSLa and TCSLu during this period.

The impact of the El Niño events and the Blob on $\mathrm{Chl}_{\mathrm{sat}}$ and PP in our study areas is clearly revealed only by the data from the inshore waters and the first season of each year (Figs. 4, 5). Sea surface temperature was higher in the offshore areas of both transects during 2014-2016 than during the other years in our data set (Fig. 3); however, $\mathrm{Chl}_{\text {sat }}$ and PP during El Niño periods and the Blob did not decrease in the offshore areas. These 2 variables did not decrease because the smallsized phytoplankton typical of oceanic regions is adapted to oligotrophic conditions and has relatively stable populations; durante fuertes condiciones de El Niño (Robinson 2016) (y también en 2016 en TCSLu).

Torres-Moye y Alvarez-Borrego (1987) reportaron biomasas de fitoplancton bajas en las aguas costeras frente al norte de Baja California en el verano de 1984, como un efecto de El Niño 1982-1983. Durante este evento, las temperaturas permanecieron altas frente a Baja California hasta la primavera de 1984, y las poblaciones de macroalgas empezaron a recuperarse en el otoño de 1984 (Hernández-Carmona 1988). El impacto del evento de 1997-1998 duró menos tiempo que el del evento de 1982-1984 (Ladah et al. 1999). El evento de 1982-1984 coincidió con un régimen caliente en el Pacífico Norte, mientras que el evento de 1997-1998 coincidió con un régimen frío (Newman et al. 2003).

El impacto de diferentes eventos ENOS en el fitoplancton y en las poblaciones de otros organismos no es igual y depende, entre otras cosas, de la fase de la Oscilación Decadal del Pacífico Norte. Kahru y Mitchell (2002) reportaron que los efectos del El Niño del tipo PO de 1997-1998 se observaron como un decremento de PP frente al centro y sur de California que empezó a mediados de 1997 y desapareció en 1998, mientras que frente al sur de Baja California, hasta el área frente a CSLa, los efectos de este El Niño fueron evidentes más tarde a mediados de 1998. Herrera-Cervantes et al. (2013) aplicaron análisis de componentes principales para describir los patrones de variabilidad interanual de TSM y $\mathrm{Chl}_{\text {sat }}$ en el área frente a punta Eugenia $\left(26-29^{\circ} \mathrm{N}, 113-116^{\circ} \mathrm{W}\right)$; estos autores sugirieron que los ciclos ENOS dominan las variaciones interanuales de TSM y $\mathrm{Ch}_{\text {sat }}$ en las aguas costeras, pero que en las aguas profundas estas variaciones son controladas más por las intrusiones de agua subártica que por los ciclos ENOS.

En el presente estudio, $\mathrm{Ch}_{\text {sat }}$ y PP disminuyeron en $>50 \%$ en las aguas costeras de TCSLa y TCSLu durante el Blob en 2014 y El Niño del tipo PO de 2015-2016, con respecto a los años como 2008, 2011 y 2012. Zaba y Rudnick (2016) reportaron que frente al sur de California la termoclina se hundió y hubo una estratificación fuerte del verano de 2014 hasta el invierno de 2015-2016. Algo similar pudo haber pasado en la parte más sureña del SCC, y esto explicaría la baja biomasa fitoplanctónica en TCSLa y TCSLu durante este periodo.

El impacto de eventos El Niño y del Blob en $\mathrm{Ch}_{\text {sat }}$ y PP sólo se aprecia con claridad en los datos de la zona costera y de la primera estación de cada año (Figs. 4, 5). La TSM de la zona oceánica de ambos transectos fue más alta durante 2014-2016 que en los otros años de nuestro conjunto de datos (Fig. 3); sin embargo, $\mathrm{Chl}_{\text {sat }}$ y PP para los periodos de El Niño y del Blob no disminuyeron en esta zona. Esto se debe a que el fitoplancton de tamaño pequeño, típico de las regiones oceánicas, está adaptado a condiciones oligotróficas y sus poblaciones son relativamente estables; la mayoría de la variabilidad de la biomasa fitoplanctónica de las aguas costeras ricas es causada por el fitoplancton de mayor tamaño (Yentsch y Phinney 1989).

Arroyo-Loranca et al. (2015) usaron datos de $\mathrm{Chl}_{\text {sat }}$ de los sensores Sea-Viewing Wide Field of View Sensor 
Ortiz-Ahumada et al.: Effects of oceanographic events on phytoplankton in a current system

most of the Chl variability in rich coastal waters is caused by large-sized phytoplankton (Yentsch and Phinney 1989).

Arroyo-Loranca et al. (2015) analyzed Sea-Viewing Wide Field-of-view Sensor (SeaWIFS) and Aqua-MODIS Chl ${ }_{\text {sat }}$ data corresponding to the 1997-2012 period for a transect off Punta Eugenia (off the central part of the peninsula), Baja California Sur, and concluded that, with the exception of the 1997-1998 EP El Niño, ENSO events did not have any significant effect in their study area. Contrary to the findings by Arroyo-Loranca et al. (2015) for the transect off Punta Eugenia, the El Niño events from the twenty-first century did have strong effects on the biology of TCSLa and TCSLu. The 2002-2005 and 2009-2010 El Niño events were of the CP type; in our study, only the 2015-2016 El Niño event was of the EP type (NOAA 2017b). The CP type events tended to occur more often in the twenty-first century (Lee and McPhaden 2010).

The effects of the 2014 Blob event and the 2015-2016 El Niño event were strong off both capes, CSLa and CSLu. While both events had similar effects on TCSLa, the Blob had an apparently stronger effect on TCSLu than El Niño did (Figs. 4, 5). The 2010 CP El Niño was the only one of this type to have a strong impact on TCSLa (Figs. 4, 5). The 2003, 2005, and 2010 CP El Niño events had a strong impact on the biology of TCSLu; their impact was similar to the impact of the Blob in 2014 and the impact of the 2015-2016 EP El Niño (Fig. 4).

According to Lee and McPhaden (2010), the 2009-2010 El Niño was one of the strongest events in the past decades, and this is reflected in the phytoplankton biomass of both transects, TCSLa and TCSLu (Figs. 4, 5). Interannual variations were different off Punta Eugenia, CSLa, and CSLu because of the different coastal dynamics (e.g., upwelling, coastal currents, jets, eddies, and meanders) at each site. The coastal countercurrent shows interannual variations and can affect the physical and biological properties of water off CSLa and CSLu. Satellite altimetry could be used in future studies to better describe these phenomena.

The effects of the ENSO events in the twenty-first century, however, were not drastically strong on TCSLa and TCSLu. Despite the significant decrease in $\mathrm{Chl}_{\text {sat }}$ and PP, $\mathrm{Ch}_{\text {sat }}$ values were often $>1 \mathrm{mg} \cdot \mathrm{m}^{-3}$ during an ENSO event or the Blob. In other words, phytoplankton biomass did not completely collapse in the southernmost part of the CCS. The $\mathrm{Chl}_{\text {sat }}$ values decreased to $<0.1 \mathrm{mg} \cdot \mathrm{m}^{-3}$ only in 2014 in the TCSLu coastal zone. Putt and Prézelin (1985) reported that, according to their filter fractionation study, over $80 \%$ of the chlorophyll-based phytoplankton biomass in the Santa Barbara Channel, California, was $<5 \mu \mathrm{m}$ during El Niño 1982-1983. These authors also reported that the population there as a whole was dominated by cyanobacteria $(0.5-1.5 \mu \mathrm{m})$, unlike the normal diatom and dinoflagellate dominance in CCS coastal waters (Lara-Lara et al. 1980, Millan-Nuñez et al. 1982). This change in phytoplankton composition during warm events like El Niño and the Blob
(SeaWIFS) y Aqua-MODIS, para un transecto similar a los aquí estudiados pero frente a punta Eugenia, Baja California Sur (frente al centro de la península), para concluir que con excepción de El Niño 1997-1998, que fue del tipo PO, sus datos de $\mathrm{Ch}_{\text {sat }}$ no mostraron ningún efecto significativo por eventos ENOS en su área de estudio. Sin embargo, contrario a lo que reportaron Arroyo-Loranca et al. (2015) para el transecto frente a punta Eugenia, para la biología de TCSLa y TCSLu sí hubo efectos fuertes causados por los eventos El Niño del siglo XXI. Los eventos El Niño de 2002-2005 y 2009-2010 fueron del tipo PC; en nuestro caso sólo el de 2015-2016 fue del tipo PO (NOAA 2017b). Había existido una tendencia de los eventos de tipo PC de ocurrir más a menudo en el siglo XXI (Lee y McPhaden 2010).

El Blob de 2014 y el evento ENOS de 2015-2016 tuvieron efectos fuertes frente a ambos cabos, CSLa y CSLu. Mientras que ambos eventos tuvieron efectos similares en TCSLa, el Blob tuvo un efecto aparentemente mayor que el del El Niño en TCSLu (Figs. 4, 5). El Niño del tipo PC de 2010 fue el único de este tipo que tuvo un impacto significativo en TCSLa (Figs. 4, 5). Los eventos El Niño del tipo PC de 2003, 2005 y 2010 tuvieron un fuerte impacto en la biología de TCSLu; su impacto fue similar al impacto del Blob en 2014 y al impacto de El Niño del tipo PO de 2015-2016 (Fig. 4).

De acuerdo con Lee y McPhaden (2010), el Niño 2009-2010 fue uno de los eventos más fuertes que ha ocurrido en las últimas décadas, y esto se aprecia en la biomasa fitoplanctónica de ambos transectos, TCSLa y TCSLu (Figs. 4, 5). La dinámica costera (e.g., surgencias, corrientes costeras, chorros, remolinos y meandros) frente a punta Eugenia, CSLa y CSLu fue la causa de las diferentes variaciones interanuales en cada sitio. La contracorriente costera presenta variaciones interanuales y puede afectar las propiedades físicas y biológicas del agua frente a CSLa y CSLu. Se podría considerar la altimetría satelital en los estudios futuros para describir estos fenómenos apropiadamente.

De cualquier forma, los efectos de los eventos ENOS del siglo XXI no fueron drásticamente fuertes en TCSLa y TCSLu. A pesar de la disminución significativa de la $\mathrm{Chl}_{\mathrm{sat}} \mathrm{y}$ PP fitoplanctónicas, $\mathrm{Chl}_{\text {sat }}$ a menudo presentó valores $>1 \mathrm{mg} \cdot \mathrm{m}^{-3}$ durante un evento ENOS o el Blob. En otras palabras, no hubo un colapso total de la biomasa fitoplanctónica en la parte más sureña del SCC. Los valores de $\mathrm{Chl}_{\text {sat }}$ disminuyeron a $<0.1 \mathrm{mg} \cdot \mathrm{m}^{-3}$ sólo en 2014 en la zona costera de TCSLu. Putt y Prézelin (1985) reportaron que, de acuerdo con su estudio de filtrado por fracciones, $>80 \%$ de la biomasa fitoplanctónica en el canal de Santa Barbara, California, fue $<5 \mu \mathrm{m}$ durante El Niño 1982-1983. Estos autores también reportaron que la comunidad fitoplanctónica estuvo dominada por cianobacterias $(0.5-1.5 \mu \mathrm{m})$, contrario a la dominancia normal de diatomeas y dinoflagelados en las aguas costeras del SCC (Lara-Lara et al. 1980, Millan-Nuñez et al. 1982). Este cambio de composición de la comunidad fitoplanctónica durante eventos cálidos como El Niño y el Blob tiene efectos drásticos en todo el ecosistema costero del SCC, incluyendo la porción más sureña. 
has drastic effects in the whole CCS coastal ecosystem, including the southernmost portion.

In the coastal zone of the transect off Punta Eugenia, SST minima and $\mathrm{Chl}_{\mathrm{sat}}$ and PP maxima were $\sim 13{ }^{\circ} \mathrm{C}, 26 \mathrm{mg} \cdot \mathrm{m}^{-3}$, and $8.7 \mathrm{~g} \mathrm{C} \cdot \mathrm{m}^{-2} \cdot \mathrm{d}^{-1}$ (Arroyo-Loranca et al. 2015), respectively. These extreme values were $\sim 3{ }^{\circ} \mathrm{C}$ lower than the SST minimum value for TCSLa, and $\sim 6{ }^{\circ} \mathrm{C}$ lower than the SST minimum value for TCSLu. The Punta Eugenia $\mathrm{Chl}_{\text {sat }}$ maximum was twice the maximum value for TCSLa and 4 times the maximum value for TCSLu, and the Punta Eugenia PP maximum was similar in the case of TCSLa and up to double the maximum value for TCSLu. Mirabal-Gómez et al. (2017) carried out a study similar to ours and analyzed Aqua-MODIS data for the same time period but for a transect off La Jolla, California, and a transect off San Quintín Bay, northwestern Baja California; however, the SST minima in the coastal zone of both their transects were up to $2.5^{\circ} \mathrm{C}$ lower than the SST minima for the TCSLa coastal zone and $\sim 6{ }^{\circ} \mathrm{C}$ lower than the SST minima for TCSLu coastal zone. In general, the lowest $\mathrm{Ch}_{\text {sat }}$ values were found in the coastal zone off CSLu (this study), the second lowest in the coastal zone off La Jolla, and the highest in the coastal zones off San Quintín Bay, Punta Eugenia, and CSLa. These differences may be due to the fact that coastal upwelling is significantly weaker off La Jolla and CSLu than off the rest of the Baja California Peninsula.

Zuria-Jordán et al. (1995) analyzed $\mathrm{Chl}_{\text {sat }}$ from the CZCS for a transect that included a section that paralleled the coast of the peninsula (from Point San Hipólito to CSLu). The section of the transect that covered the area off CSLa was very close to the coast, but the section off CSLu was relatively far and covered the oceanic zone. The $\mathrm{Chl}_{\text {sat }}$ values reported by Zuria-Jordán et al. (1995) for the area near CSLa showed the same seasonality that our values did for the TCSLa coastal zone. These authors reported $\mathrm{Chl}_{\text {sat }}$ values $>8 \mathrm{mg} \cdot \mathrm{m}^{-3}$ for June in the average year for the 1978-1986 period; in our study, $\mathrm{Ch}_{\text {sat }}$ values for June in the TCSLa climatology were up to $6.5 \mathrm{mg} \cdot \mathrm{m}^{-3}$. Interestingly, data from 2 different sensors showed similar temporal variations for the $\mathrm{Chl}_{\text {sat }}$ values from the "average years", not to mention absolute maxima were very close. Zuria-Jordán et al. (1995) reported that the area near CSLa was the richest on their transect. They also reported the strong impact of the 1982-1983 EP El Niño in the coastal area off CSLa, and indicated that the effects lasted until 1985. A comparison of average $\mathrm{Chl}_{\text {sat }}$ derived from the CZCS (Zuria-Jordán et al. 1995) and average $\mathrm{Chl}_{\text {sat }}$ derived from Aqua-MODIS for the TCSLa coastal zone (our study) shows that the latter are lower than the former by $\sim 25 \%$. Ramírez-León et al. (2015) compared Gulf of California $\mathrm{Chl}_{\text {sat }}$ data from the CZCS, SeaWIFS, and Aqua-MODIS and concluded that data from the CZCS tend to grossly overestimate $\mathrm{Chl}_{\text {sat }}$.

The PP distribution tends to run parallel to the $\mathrm{Chl}_{\text {sat }}$ distribution because when calculating PP, $\mathrm{Ch}_{\text {sat }}$ dominates despite the dependence of PP on SST, photosynthetically active
En la zona costera del transecto frente a punta Eugenia, los mínimos de TSM y máximos de $\mathrm{Ch}_{\text {sat }}$ y PP fueron $\sim 13{ }^{\circ} \mathrm{C}$, $26 \mathrm{mg} \cdot \mathrm{m}^{-3}$ y $8.7 \mathrm{~g} \mathrm{C} \cdot \mathrm{m}^{-2} \cdot \mathrm{d}^{-1}$ (Arroyo-Loranca et al. 2015). Estos valores extremos fueron $\sim 3{ }^{\circ} \mathrm{C}$ menores que los valores mínimos de TSM para TCSLa, y $\sim 6{ }^{\circ} \mathrm{C}$ menores que los valores mínimos de TSM para TCSLu. El máximo de $\mathrm{Chl}_{\mathrm{sat}}$ de punta Eugenia fue el doble comparado con el de TCSLa y 4 veces el valor máximo encontrado en TCSLu; y el máximo de PP de punta Eugenia fue similar al de TCSLa y el doble del valor máximo encontrado en TCSLu. Mirabal-Gómez et al. (2017) realizaron un estudio similar al nuestro y analizaron datos del Aqua-MODIS para el mismo periodo de estudio pero para un transecto frente a La Jolla, California, y un transecto frente a bahía San Quintín, noroeste de Baja California; sin embargo, los valores mínimos de SST para la zona costera de sus 2 transectos fueron hasta $2.5^{\circ} \mathrm{C}$ menores que los valores mínimos de SST para la zona costera de TCSLa y $\sim 6^{\circ} \mathrm{C}$ menores que los valores mínimos de SST para la zona costera de TCSLu. En general, los valores más bajos de $\mathrm{Ch}_{\text {sat }}$ se encontraron en la zona costera frente a CSLu, los siguientes más bajos en la zona costera frente a La Jolla y los más altos en las zonas costeras frente a bahía San Quintín, Punta Eugenia y CSLa. Estas diferencias posiblemente se deben a que las surgencias costeras son significativamente más débiles frente a La Jolla y CSLu que frente al resto de la península de Baja California.

Zuria-Jordán et al. (1995) analizaron la Chl $\mathrm{Sat}_{\mathrm{s}}$ del CZCS para un transecto que incluyó una sección paralela a la costa de la península (de punta San Hipólito a CSLu). La sección del transecto que cubrió el área frente a CSLa estuvo muy cerca de la costa, pero la sección frente a CSLu estuvo alejada y cubrió la zona oceánica. Los valores de $\mathrm{Chl}_{\mathrm{sat}}$ reportados por Zuria-Jordán et al. (1995) para la zona cercana a CSLa mostraron la misma estacionalidad que mostraron nuestros valores para la zona costera de TCSLa. Estos autores reportaron valores de $\mathrm{Chl}_{\text {sat }}$ de hasta $>8 \mathrm{mg} \cdot \mathrm{m}^{-3}$ para junio del año promedio del periodo 1978-1986; en nuestro estudio, los valores de $\mathrm{Chl}_{\text {sat }}$ para junio de la climatología de TCSLa fueron de hasta $6.5 \mathrm{mg} \cdot \mathrm{m}^{-3}$. Con datos de 2 sensores diferentes, es muy interesante que haya una correspondencia de temporalidad para los valores de $\mathrm{Chl}_{\text {sat }}$ de los "años promedio", además de que los valores máximos absolutos fueron muy cercanos. Zuria-Jordán et al. (1995) reportaron que la zona cercana a CSLa fue, biológicamente, la más rica de su transecto. También reportaron el impacto fuerte de El Niño del tipo PO de 1982-1983 en la zona costera frente a CSLa, e indicaron que los efectos persistieron hasta 1985. La comparación de los valores promedio de $\mathrm{Ch}_{\text {sat }}$ derivados del CZCS (Zuria-Jordán et al. 1995) y los valores de $\mathrm{Chl}_{\text {sat }}$ derivados del Aqua-MODIS para la zona costera de TCSLa (nuestro estudio) muestra que estos últimos fueron $\sim 25 \%$ menores que los primeros. Ramírez-León et al. (2015) compararon datos de $\mathrm{Chl}_{\text {sat }}$ derivados de los sensores CZCS, SeaWIFS y Aqua-MODIS para el golfo de California y concluyeron que los datos del CZCS tienden a sobrestimar por mucho los valores de $\mathrm{Chl}_{\text {sat }}$. 
Ortiz-Ahumada et al.: Effects of oceanographic events on phytoplankton in a current system

radiation, and day length. This PP behavior was also reported by Álvarez-Molina et al. (2013) for the Gulf of California. PP data show less variability than $\mathrm{Chl}_{\text {sat }}$ data because PP is integrated for the entire euphotic zone and $\mathrm{Chl}_{\mathrm{sat}}$ is only an average for the first optical depth (upper $22 \%$ of the euphotic zone). When $\mathrm{Chl}_{\text {sat }}$ is low the euphotic zone is deeper, and integration with depth increases PP.

Our inshore PP values for the first season (FebruaryJuly) could be overestimated because the VGPM assumes a mixed euphotic zone with homogenous vertical distribution of chlorophyll. In nutrient-rich coastal waters, the chlorophyll maximum is at the surface and values decrease with depth; the assumption that there are no vertical changes in chlorophyll produces PP overestimates. PP values $>4 \mathrm{~g} \mathrm{C} \cdot \mathrm{m}^{-2} \cdot \mathrm{d}^{-1}$ are unrealistic and should be taken with caution, considering only the spatial and temporal trends but not the absolute values. Álvarez-Molina et al. (2013) analyzed PP data from the Oregon State University website for the Gulf of California central region and reported that the high values they found for the Guaymas Basin, an area of intense upwelling (PP up to $7.8 \mathrm{~g} \mathrm{C} \cdot \mathrm{m}^{-2} \cdot \mathrm{d}^{-1}$ ), were possibly overestimated by $>50 \%$. Nevertheless, these authors explained that the PP trends were well interpreted, with high values during the upwelling season and very low values in the summer. The variations of our PP data are also well interpreted, with higher values during the upwelling season in February-July than in August-January. According to Kahru and Mitchell (2002), even in the CCS offshore waters (100-300 km from the coast), satellite-derived PP overestimate ship measurements by $\sim 40 \%$. The photosynthetic parameters in the VGPM algorithm for PP taken from the Oregon State University website need to be adjusted for our geographic region, this is an opportunity for future research (Arroyo-Loranca et al. 2015).

The PP data obtained from water samples and ${ }^{14} \mathrm{C}$ incubations are scarce, and it is very difficult to perform comparisons with satellite-derived data. In a strict sense, comparisons between PP data calculated with the VGPM and satellite imagery, and PP estimates from ${ }^{14} \mathrm{C}$ incubations are inappropriate because the 2 data sets have totally different temporal and spatial scales: satellite-derived data are averages for $18 \times 18 \mathrm{~km}^{2}$ areas and for a month, while ${ }^{14} \mathrm{C}$ data are instantaneous point measurements (i.e., Balch and Byrne 1994, Kahru and Mitchell 2002). Gaxiola-Castro et al. (2010) reported PP data for the CCS off the Baja California Peninsula, obtained from ${ }^{14} \mathrm{C}$ incubations during 4 cruises per year in the 1998 2007 period. Most of their sampling locations were at $>50 \mathrm{~km}$ from shore. Gaxiola-Castro et al. (2010) averaged their data set to generate a mean distribution for their study area and reported PP values in milligrams of carbon per square meter per hour. After transforming their average values to grams of carbon per square meter per day, their offshore values were $0.4-0.6 \mathrm{~g} \mathrm{C} \cdot \mathrm{m}^{-2} \cdot \mathrm{d}^{-1}$, which are in agreement with our PP values. Their average values for the inshore region fluctuated between 1.0 and $1.5 \mathrm{~g} \mathrm{C} \cdot \mathrm{m}^{-2} \cdot \mathrm{d}^{-1}$, which are also in agreement
Las gráficas de PP tienden a ser paralelas a las de $\mathrm{Ch}_{\text {sat }}$ porque cuando se calcula la $\mathrm{PP}, \mathrm{Chl}_{\text {sat }}$ domina sin importar que los cálculos de producción también dependen de la TSM, la radiación fotosintéticamente activa y la longitud del día. Este comportamiento de PP también fue reportado por Álvarez-Molina et al. (2013) para el golfo de California. Los datos de PP tienen menos variabilidad que los de $\mathrm{Chl}_{\text {sat }}$ porque PP se integra para toda la zona eufótica y $\mathrm{Chl}_{\text {sat }}$ sólo para la primera profundidad óptica (el 22\% más superficial de la zona eufótica). Cuando $\mathrm{Ch}_{\text {sat }}$ es baja, la zona eufótica es más profunda, y la integración con la profundidad aumenta la PP.

Nuestros valores de PP de la primera estación (febrero-julio), para las aguas de la zona costera, podrían estar sobrestimados porque el VGPM supone una zona eufótica bien mezclada con una distribución vertical homogénea de clorofila. En aguas costeras ricas en nutrientes el máximo de clorofila se encuentra en la superficie y los valores disminuyen con la profundidad; el suponer que no hay cambios verticales de clorofila produce sobrestimaciones de PP. Los valores de $\mathrm{PP}>4 \mathrm{~g} \mathrm{C} \cdot \mathrm{m}^{-2} \cdot \mathrm{d}^{-1}$ no son realistas y deben ser tomados con precaución, considerando solamente las tendencias de cambios espaciales y temporales y no los valores absolutos. Álvarez-Molina et al. (2013) utilizaron valores de PP de la página web de Oregon State University para analizar la región central del golfo de California y reportaron que sus valores altos para la cuenca de Guaymas, una zona de surgencias intensas (PP de hasta $7.8 \mathrm{~g} \mathrm{C} \cdot \mathrm{m}^{-2} \cdot \mathrm{d}^{-1}$ ), posiblemente fueron sobrestimados en $>50 \%$. Sin embargo, estos autores expresaron que las tendencias de cambio de sus datos de PP fueron interpretadas correctamente, con valores altos durante la estación de surgencias y valores muy bajos en verano. Las tendencias de nuestros datos de PP también fueron interpretadas correctamente, con valores más altos en el periodo de surgencias de febrero-julio que en agosto-enero. De acuerdo con Kahru y Mitchell (2002), aún en las aguas oceánicas del SCC (100-300 km de la costa), los datos de PP derivados de satélite sobrestiman las mediciones de barco en un $\sim 40 \%$. Se requiere un ajuste de los parámetros fotosintéticos que se usan en el algoritmo del VGPM para PP, de Oregon State University, para que se aplique más apropiadamente a nuestra región geográfica, y esa es una oportunidad de investigación para el futuro (Arroyo-Loranca et al. 2015).

Los datos de PP obtenidos mediante muestreos de agua e incubaciones con ${ }^{14} \mathrm{C}$ son escasos, y es muy difícil hacer comparaciones con datos derivados de satélites. En sentido estricto, la comparación entre los datos de PP derivados del VGPM e imágenes de satélite y las estimaciones de PP con ${ }^{14} \mathrm{C}$ no es apropiada porque los 2 conjuntos de datos tienen escalas temporales y espaciales totalmente diferentes: los datos derivados de satélite son promedios para áreas de $18 \times 18 \mathrm{~km}^{2}$ y para un mes, mientras que los datos de ${ }^{14} \mathrm{C}$ son mediciones instantáneas y puntuales (e.g., Balch y Byrne 1994, Kahru y Mitchell 2002). Gaxiola-Castro et al. (2010) reportaron datos de PP obtenidos con incubaciones con ${ }^{14} \mathrm{C}$ en 4 cruceros por año durante el periodo 1998-2007, en el 
with our values considering that most of their sampling sites were not close to shore.

\section{ACKNOWLEDGMENTS}

JCOA was granted a postgraduate scholarship by the National Council for Science and Technology (CONACYT, Mexico). We thank the NASA Ocean Color program for the free satellite imagery and software to process the imagery. All Multivariate ENSO Index data was provided by the NOAA Earth System Research Laboratory (USA). We thank the 2 anonymous reviewers for their constructive criticism. FJ Ponce helped with the graphic design.

\section{REFERENCES}

Álvarez-Arellano A, Molina-Cruz A. 1984. Aspectos paleoceanográficos cuaternarios del golfo de California, evidenciados por conjuntos de radiolarios. An. Inst. Cienc. Mar Limn. Contribución 475.

Álvarez-Borrego J, Álvarez-Borrego S. 1982. Temporal and spatial variability of temperature in two coastal lagoons. CalCOFI Rep. 23: 188-197.

Álvarez-Molina LL, Álvarez-Borrego S, Lara-Lara JR, Marinone SG. 2013. Annual and semiannual variations of phytoplankton biomass and production in the central Gulf of California estimated from satellite data $=$ Variaciones anual y semianual de la biomasa y producción fitoplanctónica en el golfo de California central estimadas de datos de satélite. Cienc. Mar. 39(2): 217-230. https://doi.org/10.7773/cm.v39i2.2189

Arroyo-Loranca RG, Álvarez-Borrego S, Ortiz-Figueroa M, Calderón-Aguilera LE. 2015. Spatial and temporal variation of satellite-derived phytoplankton biomass and production in the California Current System off Punta Eugenia, during 19972012 = Variación espacio-temporal de biomasa y producción fitoplanctónica derivadas de satélite en la Corriente de California frente a Punta Eugenia, de 1997-2012. Hidrobiológica 25(3): 321-334.

Ashok K, Behera SK, Rao S, Weng AH, Yamagata T. 2007. El Niño Modoki and its possible teleconnection. J. Geophys. Res. 112: C11007. https://doi.org/10.1029/2006JC003798

Bakun A, Nelson CS. 1977. Climatology of upwelling related processes off Baja California. CalCOFI Rep. 19: 107-127.

Balch WM, Byrne CF. 1994. Factors affecting the estimate of primary production from space. J. Geophys. Res. 99(C4): 75557570.

Barocio-León OA, Millán-Nuñez R, Santamaría-del-Ángel E, González-Silvera A. 2007. Phytoplankton primary productivity in the euphotic zone of the California Current System estimated by CZCS imagery $=$ Productividad primaria del fitoplancton en la zona eufótica del Sistema de la Corriente de California estimada mediante imágenes del CZCS. Cienc. Mar. 33(1): 59-72. https://doi.org/10.7773/cm.v33i1.1037

Behrenfeld MJ, Falkowsky PG. 1997. Photosynthetic rates derived from satellite-based chlorophyll concentration. Limnol. Oceanogr. 42(1): 1-20.

Bond NA, Cronin MF, Freeland H, Mantua N. 2015. Causes and impacts of the 2014 warm anomaly in the NE Pacific. Geophys. Res. Lett. 42(9): 3414-3420.

https://doi.org/10.1002/2015GL063306
SCC frente a la península de Baja California. La mayoría de sus localidades de muestreo estuvieron a $>50 \mathrm{~km}$ de la costa. Gaxiola-Castro et al. (2010) promediaron sus datos para generar una distribución media para su área de estudio y reportaron sus valores de PP en miligramos de carbono por metro cuadrado por hora. Después de transformar sus valores promedio a gramos de carbono por metro cuadrado

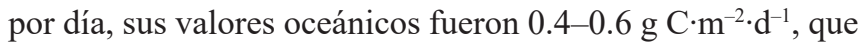
concuerdan con nuestros valores de PP. Sus valores promedio para la región costera fluctuaron entre 1.0 y $1.5 \mathrm{~g} \mathrm{C} \cdot \mathrm{m}^{-2} \cdot \mathrm{d}^{-1}$, que también concuerdan con nuestros valores considerando que la mayoría de sus sitios de muestreo no estuvieron cerca de la costa.

\section{Agradecimientos}

JCOA recibió una beca del Consejo Nacional de Ciencia y Tecnología (CONACYT, México) para sus estudios de maestría en ciencias. Agradecemos al programa Ocean Color de la NASA el permitirnos el uso gratuito de sus imágenes de satélite y la programática para procesarlas. Los datos del Índice Multivariado del ENSO se obtuvieron del Earth System Research Laboratory de la NOAA (EUA). Agradecemos a los 2 revisores anónimos sus críticas constructivas. FJ Ponce colaboró con el diseño gráfico.

Coronado-Álvarez LLA, Álvarez-Borrego S, Lara-Lara JR, SolanaArellano E, Hernández-Ayón JM, Zirino A. 2017. Temporal variations of water $\mathrm{pCO}_{2}$ and the air-water $\mathrm{CO}_{2}$ flux at a coastal location in the southern California Current System: diurnal to interannual scales $=$ Variaciones temporales de $\mathrm{pCO}_{2}$ del agua y flujos aire-agua de $\mathrm{CO}_{2}$ en una localidad costera en el sur del Sistema de la Corriente de California: de la escala diurna a la interanual. Cienc. Mar. 43(3): 137-156. http://dx.doi.org/10.7773/cm.v43i3.2707

Di Lorenzo E, Mantua N. 2016. Multi-year persistence of the 2014/15 North Pacific marine heatwave. Nat. Clim. Change 6: 1042-1047. https://doi.org/10.1038/nclimate3082

Durazo R. 2015. Seasonality of the transitional region of the California Current System off Baja California. J. Geophys. Res. 120(2): 1173-1196. https://doi.org/10.1002/2014JC010405

Durazo R, Gaxiola-Castro G. 2010. Introducción. In: GaxiolaCastro G, Durazo R (eds.), Dinámica del Ecosistema Pelágico frente a Baja California 1997-2007: Diez años de Investigaciones Mexicanas de la Corriente de California. Secretaría de Medio Ambiente y Recursos Naturales, Mexico City, pp. 13-18.

Durazo R, Ramírez-Manguilar AM, Miranda LE, Soto-Mardones LA. 2010. Climatología de variables hidrográficas. In: Gaxiola-Castro G, Durazo R (eds.), Dinámica del Ecosistema Pelágico frente a Baja California, 1997-2007: Diez años de Investigaciones de la Corriente de California. Secretaría de Medio Ambiente y Recursos Naturales, Mexico City, pp. $25-57$.

Espinosa-Carreón LT, Strub PT, Beier E, Ocampo-Torres F, Gaxiola-Castro G. 2004. Seasonal and interannual variability 
Ortiz-Ahumada et al.: Effects of oceanographic events on phytoplankton in a current system

of satellite-derived chlorophyll pigment, surface height, and temperature off Baja California. J. Geophys. Res. 109:C03039. http://dx.doi.org/10.1029/2003JC002105

Fargion GS, McGowan JA, Stewart RH. 1993. Seasonality of chlorophyll concentrations in the California Current: A comparison of two methods. CalCOFI Rep. 34: 35-50.

Gaxiola-Castro G, Álvarez-Borrego S. 1986. Primary productivity of the Mexican Pacific $=$ Productividad primaria del Pacífico mexicano. Cienc. Mar. 12(3): 26-33.

http://dx.doi.org/10.7773/cm.v12i3.519

Gaxiola-Castro G, Cepeda-Morales J, Nájera-Martínez S, EspinosaCarreón LT, De-La-Cruz-Orozco ME, Sosa-Avalos R, AguirreHernández E, Cantú-Ontiveros JP. 2010. Biomasa y producción del fitoplancton. In: Gaxiola-Castro G, Durazo R (eds.), Dinámica del Ecosistema Pelágico frente a Baja California, 1997-2007: Diez años de Investigaciones Mexicanas de la Corriente de California. Secretaría de Medio Ambiente y Recursos Naturales, Mexico City, pp. 59-85.

Gentemann CL, Fewings MR, García-Reyes M. 2017. Satellite sea surface temperatures along the West Coast of the United States during the 2014-2016 northeast Pacific marine heat wave. Geophys. Res. Lett. 44(1): 312-319. http://doi.org/10.1002/2016g1071039

Griffiths RC. 1963. Studies of oceanic fronts in the mouth of the Gulf of California, an area of tuna migrations. FAO Fish. Rep. 6: $1583-1609$.

Hernández-Carmona G. 1988. Evaluación, crecimiento y regeneración de mantos de Macrocystis pyrifera en la costa occidental de la península de Baja California, México. MSc thesis, Instituto Politécnico Nacional-Centro Interdisciplinario de Ciencias Marinas, La Paz (Baja California), 157 pp.

Herrera-Cervantes H, Lluch-Cota SE, Lluch-Cota DB, Gutiérrezde-Velasco G. 2013. Interannual correlations between sea surface temperature and concentration of chlorophyll pigment off Punta Eugenia, Baja California, during different remote forcing conditions. Ocean Sci. 10(3): 853-882. https://doi.org/10.5194/osd-10-853-2013

Hickey BM. 1998. Coastal oceanography of western North America from the tip of Baja California to Vancouver Island. In: Robinson AR, Brink KH (eds.), Coastal Segment, The Sea, Vol. 11, Wiley and Sons, New York, pp. 345-391.

Huyer A. 1983. Coastal upwelling in the California Current System. Progr. Oceanogr. 12(3): 259-284. https://doi.org/10.1016/0079-6611(83)90010-1

Kahru M, Mitchell BG. 2000. Influence of the 1997-98 El Niño on the surface chlorophyll in the California Current. Geophys. Res. Lett. 27(18): 2937-2940. https://doi.org/10.1029/2000g1011486

Kahru M, Mitchell BG. 2002. Influence of the El Niño-La Niña cycle on satellite-derived primary production in the California Current. Geophys. Res. Lett. 29(17):27-1-27-4. https://doi.org/10.1029/2002gl014963

Kao HY, Yu JY. 2009. Contrasting Eastern-Pacific and CentralPacific types of ENSO. J. Climate 22: 615-632. https://doi.org/10.1175/2008JCLI2309.1

Ladah L, Zertuche-González JA, Hernández-Carmona G. 1999. Giant kelp (Macrocystis pyrifera, Phaeophyceae) recruitment near its southern limit in Baja California after mass disappearance during ENSO 1997-1998. J. Phycol. 35(6): 11061112. https://doi.org/10.1046/j.1529-8817.1999.3561106.x

Lara-Lara JR, Alvarez-Borrego S, Small LF. 1980. Variability and tidal exchange of ecological properties in a coastal lagoon. J. Estuarine Coastal Mar. Sci. 11(6): 613-637. https://doi.org/10.1016/S0302-3524(80)80014-4
Lara-Lara JR, Bazán-Guzmán C. 2005. Distribución de clorofila y producción primaria por clases de tamaño en la costa del Pacífico mexicano $=$ Distribution of chlorophyll and primary production by seize clases along the Mexican Pacific coast. Cienc. Mar. 31(1A): 11-21. http://dx.doi.org/10.7773/cm.v31i11.83

Lee T, McPhaden MJ. 2010. Increasing intensity of El Niño in the central-equatorial Pacific. Geophys. Res. Lett. 37(14): LI4603. https://doi.org/10.1029/2010g1044007

Longhurst AR, Lorenzen CJ, Thomas WH. 1967. The role of pelagic crabs in the grazing of phytoplankton off Baja California. Ecol. 48(2): 190-200.

Lynn RJ, Collins C, Mantyla AW, Schwing FB, Baumgartner T, Hayward TL, Murphree T, Sakuma KM, Garcia J, Hyrenbach KD, Shankle A, Tegner MJ. 1998. The state of the California Current, 1997-1998: Transition to El Niño conditions. CalCOFI Rep. 39: 25-49.

Lynn RJ, Simpson JJ. 1987. The California Current System: The seasonal variability of its physical characteristics. J. Geophys. Res. 92(C12): 12947-12966. https://doi.org/10.1029/jc092ic12p12947

Mann KH, Lazier JRN. 2006. Dynamics of marine ecosystems: biological-physical interactions in the oceans. Blackwell Publishing, Malden (MA). 496 pp.

Martínez-López A, Verdugo-Díaz G. 2000. Composición y dinámica del fitoplancton en el BAC de Bahía Magdalena, B. C. S. In: Lluch-Belda D, Elorduy-Garay J, Lluch-Cota SE, PonceDíaz G (eds.), BAC: Centros de Actividad Biológica del Pacífico Mexicano. Centro de Investigaciones Biológicas del Noroeste, La Paz, Baja California, pp. 125-142.

Millan-Nuñez R, Alvarez-Borrego S, Nelson DM. 1982. Effects of physical phenomena on the distribution of nutrients and phytoplankton productivity in a coastal lagoon. Estuarine, Coastal Shelf Sci. 15(3): 317-335. https://doi.org/10.1016/0272-7714(82)90066-X

Mirabal-Gómez U, Álvarez-Borrego S, Lara-Lara JR. 2017. Satellite-derived phytoplankton biomass and production variability in 2 contrasting coastal areas: off southern California and off northern Baja California = Variabilidad de la biomasa y la producción fitoplanctónicas, derivadas de satélite, en 2 áreas costeras contrastantes: frente al sur de California y frente al norte de Baja California. Cienc. Mar. 43(4): 229-248. http://dx.doi.org/10.7773/cm.v43i4.2763

[NASA] National Aeronautical and Space Administration. 2017. Ocean Color web [accessed January 2016-February 2017]. http://oceancolor.gsfc.nasa.gov/.

Newman M, Compo GP, Alexander MA. 2003. ENSO-forced variability of the Pacific decadal oscillation. J. Clim. 16: 38533857.

[NOAA] National Oceanic and Atmospheric Administration. 2017a. Office of satellite and products operations. National environmental satellite, data, and information services [accessed March 2017]. http://www. ospo.noaa.gov.

[NOAA] National Oceanic and Atmospheric Administration. 2017b. MEI Index [accessed March 2017]. http://www.esrl. noaa.gov/psd/enso/mei/table.html.

Pegau WS, Boss E, Martínez A. 2002. Ocean color observations of eddies during the summer in the Gulf of California. Geophys. Res. Lett. 29(9): 6-1-6-3. https://doi.org/10.1029/2001g1014076

Putt M, Prézelin BB. 1985. Observations of diel patterns of photosynthesis in cyanobacteria and nannoplankton in the Santa Barbara Channel during "El Niño". J. Plankton Res. 7(6): 779-790. https://doi.org/10.1093/plankt/7.6.779 
Ramírez-León MR, Álvarez-Borrego S, Turrent-Thompson C, Gaxiola-Castro G, Heckel-Dziendzielewski G. 2015. Nutrient input from the Colorado River water to the northern Gulf of California is not required to maintain its pelagic ecosystem productive $=$ El aporte de nutrientes del río Colorado al norte del golfo de California no se requiere para mantener un ecosistema pelágico productivo. Cienc. Mar. 41(2): 169-188. http://dx.doi.org/10.7773/cm.v41i2.2483

Reid JL. 1988. Physical Oceanography, 1947-1987. CalCOFI Rep. 29: 42-65.

Robinson CJ. 2016. Evolution of the 2014-2015 sea surface temperature warming in the central west coast of Baja California, Mexico, recorded by remote sensing. Geophys. Res. Lett. 43(13): 7066-7071. https://doi.org/10.1002/2016g1069356

Santamaría-del-Ângel E, Álvarez-Borrego S, Millán-Nuñez R, Müller-Karger FE. 1999. Sobre el efecto débil de las surgencias de verano en la biomasa fitoplanctónica del Golfo de California. Rev. Soc. Mex. Hist. Nat. 49: 207-212.

Torres-Moye G, Alvarez-Borrego S. 1987. Effects of the 1984 El Niño on the summer phytoplankton of a Baja California upwelling zone. J. Geophys. Res. 92(C13): 14383-14386. https://doi.org/10.1029/jc092ic13p14383

Traganza ED. 1985. Application of satellites to chemical oceanography. In: Zirino A (ed.). Mapping Strategies in
Chemical Oceanography. Am. Chem. Soc., Advances in Chemistry Series 209, Washington DC, pp. 373-392. https://doi.org/10.1021/ba-1985-0209.ch019

Walsh JJ, Whitledge TE, Kelly JC, Hunstman SA, Pillsbury RD. 1977. Further transition states of the Baja California upwelling ecosystem. Limnol. Oceanogr. 22(2): 264-280.

Warsh CE, Warsh KL, Staley RC. 1973. Nutrients and water masses at the mouth of the Gulf of California. Deep-Sea Res. 20(6): $561-570$. https://doi.org/10.1016/0011-7471(73)90080-6

Yentsch CS. 1981. Phytoplankton growth in the sea, a coalescence of disciplines. In: Falkowski PG (ed.). Primary Productivity in the Sea. Plenum Press, New York, pp. 17-32.

Yentsch CS, Phinney DA. 1989. A bridge between ocean optics and microbial ecology. Limnol. Oceanogr. 34(8): 1694-1705. https://doi.org/10.4319/1o.1989.34.8.1694

Zaba KD, Rudnick DL. 2016. The 2014-2015 warming anomaly in the Southern California Current System observed by underwater gliders. Geophys. Res. Lett. 43(3): 1241-1248. https://doi.org/10.1002/2015GL067550

Zuria-Jordán IL, Álvarez-Borrego S, Santamaría-del-Ángel E, Müller-Karger FE. 1995. Estimación de la biomasa fitoplanctónica, derivada de datos de satélite, frente a Baja California Sur = Satellite-derived estimates of phytoplankton biomass off Southern Baja California. Cienc. Mar. 21(3): 265-280. http://dx.doi.org/10.7773/cm.v21i3.998

Received March 2017, Accepted August 2017. 